\title{
Synthesis, and Molecular Structure Investigations of a New $s$-Triazine Derivatives Incorporating Pyrazole/Piperidine/ Aniline Moieties
}

\author{
Ihab Shawish $^{1}\left(\mathbb{D}\right.$, Saied M. Soliman ${ }^{2}\left(\mathbb{D}\right.$, Matti Haukka $^{3}\left(\mathbb{D}\right.$, Ali Aldalbahi ${ }^{1}$, Assem Barakat ${ }^{1, *(D)}$ \\ and Ayman El-Faham 2,*(D)
}

\section{check for}

updates

Citation: Shawish, I.; Soliman, S.M.; Haukka, M.; Aldalbahi, A.; Barakat,

A.; El-Faham, A. Synthesis, and

Molecular Structure Investigations of a

New s-Triazine Derivatives

Incorporating Pyrazole/Piperidine/ Aniline Moieties. Crystals 2021, 11, 1500. https://doi.org/10.3390/ cryst11121500

Academic Editors: Benoit Heinrich and Catherine P. Raptopoulou

Received: 21 October 2021

Accepted: 30 November 2021

Published: 2 December 2021

Publisher's Note: MDPI stays neutral with regard to jurisdictional claims in published maps and institutional affiliations.

Copyright: (c) 2021 by the authors. Licensee MDPI, Basel, Switzerland. This article is an open access article distributed under the terms and conditions of the Creative Commons Attribution (CC BY) license (https:// creativecommons.org/licenses/by/ $4.0 /)$.
1 Department of Chemistry, College of Science, King Saud University, P.O. Box 2455, Riyadh 11451, Saudi Arabia; ishawish@psu.edu.sa (I.S.); aaldalbahi@ksu.edu.sa (A.A.)

2 Department of Chemistry, Faculty of Science, Alexandria University, P.O. Box 426, Alexandria 21321, Egypt; saied1soliman@yahoo.com

3 Department of Chemistry, University of Jyväskylä, P.O. Box 35, 40014 Jyväskylä, Finland; matti.o.haukka@jyu.fi

* Correspondence: ambarakat@ksu.edu.sa (A.B.); aymanel_faham@hotmail.com (A.E.-F.); Tel.: +966-11467-5901 (A.B.); Fax: +966-11467-5992 (A.B.)

\begin{abstract}
In this work, we synthesized two new s-triazine incorporates pyrazole/piperidine/aniline moieties. Molecular structure investigations in the light of X-ray crystallography combined with Hirshfeld and DFT calculations were presented. Intermolecular interactions controlling the molecular packing of 4-(3,5-dimethyl-1H-pyrazol-1-yl)-N-phenyl-6-(piperidin-1-yl)-1,3,5-triazin-2-amine; 5a and $N$-(4-bromophenyl)-4-(3,5-dimethyl-1H-pyrazol-1-yl)-6-(piperidin-1-yl)-1,3,5-triazin-2-amine; $5 \mathbf{b}$ were analyzed using Hirshfeld calculations. The most dominant interactions are the H...H, N...H and H...C contacts in both compounds. The N...H and H...C interactions in $\mathbf{5 a}$ and the N...H, Br...H and $\mathrm{H} . . . \mathrm{H}$ interactions in $\mathbf{5 b}$ are the most important. In addition, DFT calculations were used to compute the molecular structures of $\mathbf{5 a}$ and $\mathbf{5 b}$; then, their electronic properties, as well as the ${ }^{1} \mathrm{H}$ and ${ }^{13} \mathrm{C}$-NMR spectra, were predicted. Both compounds are polar where 5a (1.018 Debye) has lower dipole moment than $5 \mathbf{b}$ (4.249 Debye). The NMR chemical shifts were calculated and very good correlations between the calculated and experimental data were obtained $\left(R^{2}=0.938-0.997\right)$.
\end{abstract}

Keywords: s-triazine; pyrazole; hydrazino-s-triazine; Hirshfeld calculations

\section{Introduction}

$s$-Triazine scaffold has been extensively studied in the literature due to its wide applications in different fields, including coordination chemistry [1] and drug discovery development, such as Enasidenib (Idhifa), as a representative example, having the s-triazine privileged structure, which has been approved by FDA in 2017 for the IDH2-positive acute leukemia treatment $[2,3]$. Other pharmaceutical applications of the substituted s-triazine core structure were reported as fungicidal [4], antiprotozoal [5], antibacterial [6], sedative and anti-inflammatory [7], cytotoxic [8], antiviral [9], analgesic [10], and herbicide activity [11].

A combination of the s-triazine privileged structure with other $N$-heterocycles such as pyrazoles [12-14] and quinazoline have raised a great of attention in cancer chemotherapeutics targeting enzyme inhibitors such as TK and EGFR inhibitors [15,16].

In addition, s-triazine core structure has gained attention in the pharmaceutical industry but has also had a great impact in the polymer industrial applications due to ease of functionalization and mechanical and thermal stability [17]. Indeed, this fascinating structure is exploited in the metal-organic framework (MOFs) [18] as well as the storage and capture of carbon dioxide chemistry [19-21]. 
Several examples that have been reported in the literature have showed that replacement of the three chlorine atoms in the 2,4,6-trichlorotriazine (TCT) with different $\mathrm{N}$-heterocycles or amines are an important task and exhibited several applications [22-24] (Figure 1). For example, El-Faham et al. have been designed and synthesized in a series of $s$-triazine hybrids comprising mon-/di-pyrazolyl along with piperidine moiety, which were subsequently assessed in vitro towards cancer activity and also in vivo toxicity in zebrafish embryos [25] (Compound I, Figure 1).<smiles>CC(C)[R6]OCc1nc(N)nc(Nc2ccccc2)n1</smiles><smiles>[R]c1nc(N2CCCCC2)nc(-n2nc(C)cc2C)n1</smiles>

la, $R=$ Piperidine Ib, $R=3,5$-dimethyl-pyrazole<smiles>CN(C)c1nc(Cl)nc(NC2=NN(c3ccc(C(F)(F)F)cc3)C(c3ccc(C(F)(F)F)cc3)C2)n1</smiles><smiles>Sc1nnc(-c2ccccc2)n1Nc1nc(NC2CCCCC2)nc(NC2CCCCC2)n1</smiles><smiles>[R]c1ccccc1Nc1nc(Nc2ccccc2)nc(N(C=S)CC)n1</smiles>

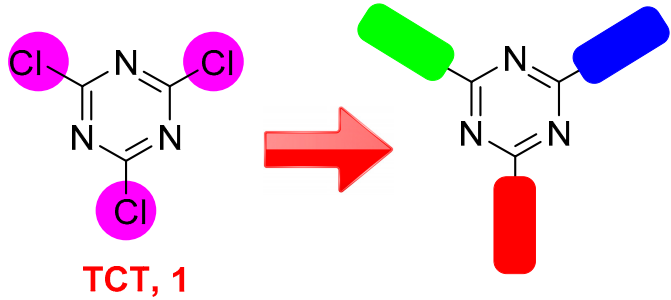

Figure 1. Some reported hybrids-based s-triazine (I-IV) and our target product from 2,4,6-trichlorotriazine (TCT, 1) with different moieties.

Matthew A. Sanders et al., have reported a tri-substituted s-triazine as a novel and lead compound TZ9 (Figure 1) for selective RAD6B inhibitory activity and cellular anti-cancer activity [26]. El-Hamamsy and co-workers have been designed and synthesized a new scaffold-based, s-triazine-targeting hDHFR for lung cancer treatment. Compound II was found to have significant activity compared to methotrexate against the A549 cancer cell line [27]. Prashanth et al., reported novel lead compounds based on s-triazine tethered pyrazole moiety as a potential anti-cancer agent targeting EFGR kinase inhibitors with $\mathrm{IC}_{50}=229.4 \mathrm{~nm}$ (Compound III, Figure 1) [28]. Additionally, the Singh research team have reported a new series of hybrids derived from monastrol-1,3,5-triazine and were studied in vitro and in vivo for their anti-cancer activity. The results indicated the potential efficacy of compound IV against cancer via inhibition of EGFR-TK (Figure 1) [29].

Therefore, the synthesis of new s-triazine derivatives connected to different amines such as aniline, piperidine, or heterocycles, such as pyrazole rings, could be useful for the drug discovery or as a new material for different applications.

In continuation of this research program towards the synthesis of $s$-triazine core structure with different moieties for biological activity applications. We reported here, the synthesis and characterization of two new compounds based on an s-triazine privileged structure having three different moieties such pyrazole, piperidine, and an aniline derivative. The chemical insights of the new compounds were explored via combined experimental and computational investigations. 


\section{Materials and Methods}

Chemicals were purchased from Sigma-Aldrich Company (Chemie GmbH, Taufkirchen, Germany). ${ }^{1} \mathrm{H}$ - and ${ }^{13} \mathrm{C}-\mathrm{NMR}$ spectra were recorded in $\mathrm{CDCl}_{3}$ and DMSO- $d_{6}$ on a Jeol Spectrometer (Jeol, Tokyo, Japan) (400 MHz and $500 \mathrm{MHz})$. Infrared spectra were recorded on a Thermo Scientific Nicolet iS10 FT-IR spectrometer (Thermo Fisher Scientific, Waltham, MA, USA). X-ray diffraction data were collected on a Rigaku Oxford Diffraction Supernova diffractometer and processed with CrysAlisPro software v. 1.171.41.93a (Rigaku Oxford Diffraction, Yarnton, $\mathrm{UK}, 2020)$ using $\mathrm{Cu} \mathrm{K} \alpha$ radiation.

Compounds $\mathbf{2} \mathbf{a}, \mathbf{b}$ and $\mathbf{3} \mathbf{a}, \mathbf{b}$, which were required for this study, were prepared according to reported literature [25]. The synthetic pathway for the desired compounds are depicted in Scheme 1.<smiles>Clc1nc(Cl)nc(Cl)n1</smiles>

1
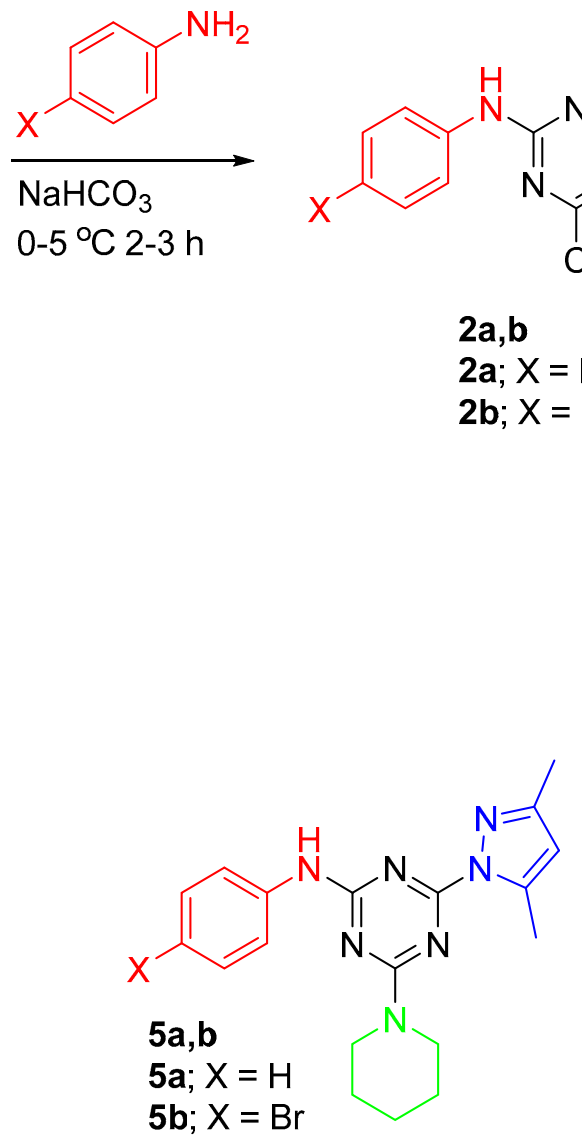<smiles>[X]c1ccc(Nc2nc(Cl)nc(Cl)n2)cc1</smiles>

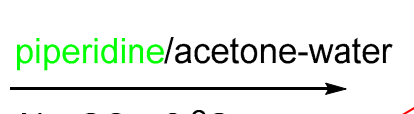
$\mathrm{Na}_{2} \mathrm{CO}_{3}, 0^{\circ} \mathrm{C}$ to rt. overnight

$2 a, b$

$2 \mathrm{a} ; \mathrm{X}=\mathrm{H}$

$\mathrm{X}=\mathrm{Br}$

Scheme 1. Synthesis of a new hits tethered pyrazole/piperidine/aniline-based s-triazine privileged structure.

\section{General procedure (GP1) for the synthesis of compounds $4 a, b$}

For the synthesis of monohydrazino $s$-triazine derivatives, $\mathbf{4 a}, \mathbf{b}$ excess hydrazine hydrate- $80 \%$ (5.0 equiv.) was added dropwise to a solution of disubstituted s-triazine derivative $3 \mathbf{a}, \mathbf{b}$ (1.0 equiv.) in refluxing ethanol overnight, the evolution of the reaction was monitored by TLC (ethyl acetate/hexane 3:7). After completion of the reaction, the solution was cooled, and the precipitate was filtered and washed with diethyl ether to afford monohydrazino s-triazine derivatives as white solids in a very good yield and purity. Spectroscopic data fully agreed with the proposed structures. All monohydrazino s-triazine derivatives were used directly without further purification in the next step to synthesize the corresponding pyrazolo $s$-triazene derivatives. 


\section{4-Hydrazinyl-N-phenyl-6-(piperidin-1-yl)-1,3,5-triazin-2-amine $4 a$}<smiles>NNc1nc(Nc2ccccc2)nc(N2CCCCC2)n1</smiles>

The reaction between 4-chloro- $N$-phenyl-6-(piperidin-1-yl)-1,3,5-triazin-2-amine 3a $(1.45 \mathrm{~g}, 5 \mathrm{mmol})$ and excess hydrazine hydrate $(1.26 \mathrm{~mL}, 25.0 \mathrm{mmol})$ was carried out in refluxing ethanol $(30 \mathrm{~mL})$ for $12 \mathrm{~h}$ according to the general procedure (GP1). TLC analysis (ethyl acetate/hexane 3:7) showed a single spot which indicated completion of the reaction and formation of the product $4 \mathbf{a}$ as a pure compound. Thereafter, the resulting white solid was filtered and used in the next step without further purification $(1.10 \mathrm{~g}, 3.86 \mathrm{mmol}, 77 \%)$, m.p. ${ }^{136}-140{ }^{\circ} \mathrm{C}$; IR $\left(\mathrm{KBr}, \mathrm{cm}^{-1}\right)$ : 3288, $3160(2 \mathrm{NH}), 1586(\mathrm{C}=\mathrm{N}), 1506-1440$ (aromatic C-C); ${ }^{1} \mathrm{H}-\mathrm{NMR}\left(400 \mathrm{MHz}, \mathrm{DMSO}-d_{6}\right) \delta 9.00\left(\mathrm{~s}, 1 \mathrm{H},-\mathrm{NHNH}_{2}\right), 7.95(\mathrm{~s}, 1 \mathrm{H},-\mathrm{NH}-), 7.74$ $(\mathrm{d}, J=8.0 \mathrm{~Hz}, 2 \mathrm{H}, \mathrm{H}-2, \mathrm{H}-6), 7.23(\mathrm{t}, J=7.7 \mathrm{~Hz}, 2 \mathrm{H}, \mathrm{H}-3, \mathrm{H}-5), 6.90(\mathrm{t}, J=7.3 \mathrm{~Hz}, 1 \mathrm{H}, \mathrm{H}-4)$, $3.72\left(\mathrm{~s}, 4 \mathrm{H}, 2 \mathrm{NCH}_{2}-\right), 1.61\left(\mathrm{q}, J=6.2 \mathrm{~Hz}, 2 \mathrm{H},-\mathrm{CH}_{2}-\right), 1.52-1.45\left(\mathrm{~m}, 4 \mathrm{H}, 2-\mathrm{CH}_{2}-\right) ;{ }^{13} \mathrm{C}-\mathrm{NMR}$ $\left(126 \mathrm{MHz}, \mathrm{DMSO}-d_{6}\right) \delta 168.19,164.62,164.40(3 \mathrm{C}=\mathrm{N}), 141.13(\mathrm{C} 1), 128.85(\mathrm{C} 3,5), 121.71(\mathrm{C} 4)$, $119.91(\mathrm{C} 2,6), 44.11\left(2 \mathrm{CH}_{2} \mathrm{~N}\right), 25.99\left(2-\mathrm{CH}_{2}-\right), 24.92\left(-\mathrm{CH}_{2}\right)$; Chemical Formula: $\mathrm{C}_{14} \mathrm{H}_{19} \mathrm{~N}_{7}$.

N-(4-Bromophenyl)-4-hydrazinyl-6-(piperidin-1-yl)-1,3,5-triazin-2-amine<smiles>NNc1nc(Nc2ccc(Br)cc2)nc(N2CCCCC2)n1</smiles>

The reaction of $\mathrm{N}$-(4-bromophenyl)-4-chloro-6-(piperidin-1-yl)-1,3,5-triazin-2-amine $3 \mathbf{b}(1.843 \mathrm{~g}, 5.00 \mathrm{mmol})$ and excess hydrazine hydrate $(1.26 \mathrm{~mL}, 25.0 \mathrm{mmol})$ in refluxing ethanol $(35 \mathrm{~mL})$ was carried out according to the general procedure (GP1). After $12 \mathrm{~h}$, the TLC analysis (ethyl acetate/hexane 3:7) provided evidence that the desired hydrazine derivative $\mathbf{4 b}$ was produced in its pure form. Ethanol and excess hydrazine were evaporated by vacuo as a part of work up procedure followed by an addition of $15 \mathrm{~mL}$ of n-hexane to the product as a white precipitate, which was collected by filtration (1.55 g, $4.75 \mathrm{mmol}, 95 \%)$; 198-201 ${ }^{\circ} \mathrm{C}$; IR ( $\left.\mathrm{KBr}, \mathrm{cm}^{-1}\right)$ : 3224, $3230(2 \mathrm{NH}), 1581(\mathrm{C}=\mathrm{N}), 1506-1440$ (aromatic C-C); ${ }^{1} \mathrm{H}-\mathrm{NMR}\left(400 \mathrm{MHz}, \mathrm{DMSO}-d_{6}\right) \delta 9.16\left(\mathrm{~s}, 1 \mathrm{H},-\mathrm{NHNH}_{2}\right), 7.97(\mathrm{~s}, 1 \mathrm{H},-\mathrm{NH}-)$, $7.74(\mathrm{~d}, J=8.5 \mathrm{~Hz}, 2 \mathrm{H}, \mathrm{H}-2, \mathrm{H}-6), 7.38$ (d, J = 8.6 Hz, 2H, H-3, H-5), 4.19 (s, $1 \mathrm{H},-\mathrm{NH}), 3.71$ $\left(\mathrm{s}, 4 \mathrm{H}, 2 \mathrm{NCH}_{2}-\right), 1.60\left(\mathrm{q}, J=5.8 \mathrm{~Hz}, 2 \mathrm{H},-\mathrm{CH}_{2}-\right), 1.51-1.44\left(\mathrm{~m}, 4 \mathrm{H}, 4 \mathrm{H}, 2-\mathrm{CH}_{2}-\right) ;{ }^{13} \mathrm{C}-\mathrm{NMR}$ $\left(101 \mathrm{MHz}, \mathrm{DMSO}-d_{6}\right) \delta 168.35,164.64(3 \mathrm{C}=\mathrm{N}), 140.71(\mathrm{C} 1), 131.57(\mathrm{C} 4), 121.80(\mathrm{C} 3,5), 113.12$ $(\mathrm{C} 2,6), 44.18\left(2 \mathrm{CH}_{2} \mathrm{~N}-\right), 26.04\left(2-\mathrm{CH}_{2}-\right), 24.96\left(-\mathrm{CH}_{2}-\right)$; Chemical Formula: $\mathrm{C}_{14} \mathrm{H}_{18} \mathrm{BrN}_{7}$.

\section{General procedure (GP2) for the synthesis of compounds $5 a, b$}

For the synthesis of mono-pyrazole $s$-triazine derivatives $\mathbf{5 a}, \mathbf{b}$, a solution of acetyl acetone (1.2 equiv.) in DMF was added to a stirring solution of monohydrazino s-triazene derivative $4 \mathbf{a}, \mathbf{b}$ (1 equivalent) in DMF at rt. The reaction mixture was treated with triethylamine ( 0.8 equiv.) and was allowed to reflux while stirring overnight. It was noticed that the reactivity of bromo-hydrazino $s$-triazine derivative $5 \mathbf{b}$ was relatively lower than that of the other hydrazino s-triazine derivatives, which required starting with excess amounts of acetylacetone (1.8 equiv.) and triethylamine (1.2 equiv.) for each equivalent of $4 \mathbf{b}$. After completion of the reaction as identified by TLC analysis (ethyl acetate/hexane 5:5), it was allowed to cool down to rt., and then a small amount of ice-cold water was added with continuous stirring for $30 \mathrm{~min}$. Thereafter, the reaction mixture was placed into an ice 
bath for $1 \mathrm{~h}$ and the precipitate of the product was separated by filtration and washed with several portions of ice-cold water and then dried overnight under vacuum to afford the product a very good yield. Some of the final products needed further purification by column chromatography on silica gel (gradient 20-60\% EtOAc in hexane).

\section{4-(3,5-Dimethyl-1H-pyrazol-1-yl)-N-phenyl-6-(piperidin-1-yl)-1,3,5-triazin-2-amine}<smiles>Cc1cc(C)n(-c2nc(Nc3ccccc3)nc(N3CCCCC3)n2)n1</smiles>

According to the general procedure (GP2), 4-hydrazinyl- $N$-phenyl-6-(piperidin-1yl)-1,3,5-triazin-2-amine $4 a$ ( $428 \mathrm{mg}, 1.50 \mathrm{mmol})$ was reacted with acetylacetone (180 mg, $1.80 \mathrm{mmol})$ in the presence of triethylamine (121 mg, $1.20 \mathrm{mmol})$ in refluxing DMF $(10 \mathrm{~mL})$ The reaction progress was monitored by TLC (ethyl acetate/hexane 5:5), which indicated the completion of the reaction after $8 \mathrm{~h}$. Subsequently, the reaction mixture was stirred with ice water and placed in an ice bath for about $30 \mathrm{~min}$ to create the white precipitate of compound 5a, which was filtered, washed with water, and dried under vacuum (503 mg, $1.44 \mathrm{mmol}, 96 \%)$; m.p. $195-197^{\circ} \mathrm{C}$; IR (KBr, cm $\left.{ }^{-1}\right)$ : $3440(\mathrm{NH}), 1588(\mathrm{C}=\mathrm{N}), 1512-1440$ (aromatic C-C); ${ }^{1} \mathrm{H}-\mathrm{NMR}\left(400 \mathrm{MHz}, \mathrm{CDCl}_{3}\right) \delta 7.57$ (s, 2H, H-2, H-6), 7.33 (s, 2H, H-3, H-5), 7.05 (s, 1H, H-4), 6.00 (s, 1H, H-4; Pyrazole), 3.87-3.78 (m, 4H, 2NCH $\left.2_{2}^{-}\right), 2.66$ (s, 3H, H-b), $2.32(\mathrm{~s}, 3 \mathrm{H}, \mathrm{H}-\mathrm{a}), 1.71\left(\mathrm{~s}, 2 \mathrm{H},-\mathrm{CH}_{2}-\right), 1.66\left(\mathrm{~s}, 4 \mathrm{H}, 2-\mathrm{CH}_{2}-\right) ;{ }^{13} \mathrm{C}-\mathrm{NMR}\left(101 \mathrm{MHz}, \mathrm{CDCl}_{3}\right)$ $\delta$ 164.75, 164.19, $162.63(3 \mathrm{C}=\mathrm{N}), 151.58$ (C5; Pyraz.), 143.37 (C3; Pyraz.), 138.82 (C1, Ph), 128.94 (C3,5; Ph), 123.13 (C4, Ph), 119.99 (C2,6; Ph), 110.84 (C4, Pyraz.), $45.09\left(2 \mathrm{CH}_{2} \mathrm{~N}-\right)$, $25.83\left(2-\mathrm{CH}_{2}-\right), 24.75\left(-\mathrm{CH}_{2}-\right), 16.21,14.10\left(2 \mathrm{CH}_{3}\right.$; Pyraz.); Chemical Formula: $\mathrm{C}_{19} \mathrm{H}_{23} \mathrm{~N}_{7}$.

\section{Compound 5a was recrystallized from ethanol:}

About $15 \mathrm{~mL}$ of absolute ethanol was added to compound $\mathbf{5 a}$ and the mixture was heated gently until the entire amount dissolved completely. Thereafter, the solution was allowed to cool at rt. overnight to afford the product its crystalline form.

$\mathrm{N}$-(4-Bromophenyl)-4-(3,5-dimethyl-1H-pyrazol-1-yl)-6-(piperidin-1-yl)-1,3,5-triazin-2-amine<smiles>Cc1cc(C)n(-c2nc(Nc3ccc(Br)cc3)nc(N3CCCCC3)n2)n1</smiles>

The reaction of $\mathrm{N}$-(4-bromophenyl)-4-hydrazinyl-6-(piperidin-1-yl)-1,3,5-triazin-2amine $4 \mathrm{~b}$ (728 $\mathrm{mg}, 2.00 \mathrm{mmol})$ and acetylacetone $(360 \mathrm{mg}, 3.6 \mathrm{mmol})$ in the presence of triethylamine $(243 \mathrm{mg}, 2.40 \mathrm{mmol})$ was carried out in refluxing DMF $(15 \mathrm{~mL})$ while stirring overnight. Once the reaction was complete based on TLC analysis (ethyl acetate/hexane 5:5), it was cooled in an ice bath while stirring with $15 \mathrm{~mL}$ of ice water to afford the product $\mathbf{5 b}$ as a white precipitate, which was separated by filtration, washed with water, and dried under vacuum (668 mg, $1.57 \mathrm{mmol}, 79 \%)$; m.p. $198-201^{\circ} \mathrm{C}$; IR $\left(\mathrm{KBr}, \mathrm{cm}^{-1}\right)$ : $3444(\mathrm{NH}), 1585$ $(\mathrm{C}=\mathrm{N}), 1530-1480$ (aromatic C-C); ${ }^{1} \mathrm{H}-\mathrm{NMR}\left(400 \mathrm{MHz}, \mathrm{CDCl}_{3}\right) \delta 7.44-7.46(\mathrm{~d}, \mathrm{~J}=13.3 \mathrm{~Hz}$,

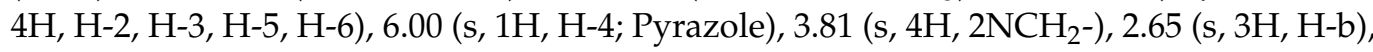


$2.31(\mathrm{~s}, 3 \mathrm{H}, \mathrm{H}-\mathrm{a}), 1.71\left(\mathrm{~s}, 2 \mathrm{H},-\mathrm{CH}_{2}-\right), 1.64\left(\mathrm{~s}, 4 \mathrm{H}, 2-\mathrm{CH}_{2}-\right) ;{ }^{13} \mathrm{C}-\mathrm{NMR}\left(126 \mathrm{MHz}, \mathrm{CDCl}_{3}\right) \delta$ 160.70-168.00 (3C=N), 151.02 (C5; Pyraz.), 142.37 (C3; Pyraz.), 136.56 (C1, Ph), 130.78 (C3,5; $\mathrm{Ph}), 120.65$ (C2,6; Ph), $114.82(\mathrm{C} 4 ; \mathrm{Ph}), 110.10$ (C4; Pyraz.), $44.22\left(2 \mathrm{CH}_{2} \mathrm{~N}-\right), 24.73\left(2-\mathrm{CH}_{2}-\right)$, $23.58\left(-\mathrm{CH}_{2}-\right), 15.06,13.02\left(2 \mathrm{CH}_{3} ;\right.$ Pyraz.); Chemical Formula: $\mathrm{C}_{19} \mathrm{H}_{22} \mathrm{BrN}_{7}$.

\section{Compound $5 b$ was recrystallized from DCM/Diethyl ether:}

Compound $\mathbf{5 b}$ was dissolved in about $10 \mathrm{~mL}$ of DCM with gentle heating until the dissolution was complete, then a layer of diethyl ether $(50 \mathrm{~mL})$ was allowed to slide through the flask. The crystals of compound $\mathbf{5 b}$ were collected after $48 \mathrm{~h}$.

\section{Crystal structure determination}

The technical experimental method for the mounting data and solved the chemical structures [30-33] are amended in the Supplementary Materials (SI). The crystallographic details are summarized in Table 1.

Table 1. Crystal Data of compounds $5 \mathbf{a}$ and $\mathbf{5 b}$.

\begin{tabular}{|c|c|c|}
\hline & $5 a$ & $5 b$ \\
\hline CCDC & 2113908 & 2113909 \\
\hline empirical formula & $\mathrm{C}_{19} \mathrm{H}_{23} \mathrm{~N}_{7}$ & $\mathrm{C}_{19} \mathrm{H}_{22} \mathrm{BrN}_{7}$ \\
\hline fw & 349.44 & 428.34 \\
\hline temp $(\mathrm{K})$ & $120(2)$ & $120(2)$ \\
\hline$\lambda(\AA)$ & 1.54184 & 1.54184 \\
\hline cryst syst & Orthorhombic & Orthorhombic \\
\hline space group & $\mathrm{Pbca}$ & $\mathrm{Pbcn}$ \\
\hline$a(\AA)$ & $11.49940(10)$ & $37.4570(3)$ \\
\hline$b(\AA)$ & 14.91530(10) & $8.62930(10)$ \\
\hline$c(\AA)$ & $21.10870(10)$ & $24.8053(2)$ \\
\hline$V\left(\AA^{3}\right)$ & $3620.50(4)$ & 8017.76(13) \\
\hline Z & 8 & 16 \\
\hline$\rho_{\text {calc }}\left(\mathrm{Mg} / \mathrm{m}^{3}\right)$ & 1.282 & 1.419 \\
\hline$\mu(\mathrm{Mo} \mathrm{K} \alpha)\left(\mathrm{mm}^{-1}\right)$ & 0.648 & 2.940 \\
\hline No. reflns. & 56200 & 63091 \\
\hline Unique reflns. & 3819 & 8430 \\
\hline Completeness to $\theta=67.684^{\circ}$ & $\% 100$ & $\% 100$ \\
\hline $\operatorname{GOOF}\left(F^{2}\right)$ & 1.028 & 1.038 \\
\hline$R_{\text {int }}$ & 0.0304 & 0.0301 \\
\hline$R_{1}^{\mathrm{a}}(I \geq 2 \sigma)$ & 0.0347 & 0.0321 \\
\hline$w R_{2}{ }^{b}(I \geq 2 \sigma)$ & 0.0893 & 0.0822 \\
\hline
\end{tabular}

${ }^{a} R_{1}=\Sigma|| F_{\mathrm{o}}|-| F_{\mathrm{c}}|| / \Sigma\left|F_{\mathrm{o}}\right| \cdot{ }^{b} w R_{2}=\left[\Sigma\left[w\left(F_{\mathrm{o}}{ }^{2}-F_{\mathrm{c}}{ }^{2}\right)^{2}\right] / \Sigma\left[w\left(F_{\mathrm{o}}{ }^{2}\right)^{2}\right]\right]^{1 / 2}$.

\section{Computational Study}

Computational investigation software [34-40] employed in this study are provided in the Supplementary Materials (SI).

\section{Results and Discussion}

\subsection{Chemistry}

The target s-triazine hybridized structures with different moieties have been synthesized, as shown in Scheme 1. Insertion of the aniline derivative was carried out initially via reaction of 2,4,6-trichlorotriazine (TCT) with the substituted aniline at $0-5^{\circ} \mathrm{C}$ for $2-3 \mathrm{~h}$. Subsequently, the second reactive chlorine atom was replaced by the piperidine moiety in acetone-water as a solvent at $0{ }^{\circ} \mathrm{C}$ to rt. overnight. Next, the least reactive chlorine atom was replaced with hydrazine. Finally, the hydrazine derivative was cyclized with acetyl acetone to afford the last pyrazole moiety in DMF under reflux condition. The chemical features of the synthesized s-triazine having different three moieties were assigned and confirmed via NMR, IR, and a single crystal X-ray diffraction analysis technique. 


\subsection{Crystal Structure Description}

The X-ray structure of $\mathbf{5 a}$ showing atom numbering and thermal ellipsoids drawn at 30\% probability level is shown in Figure 2A. The compound crystallized in the orthorhombic system and Pbca space group with unit cell parameters of $a=11.49940(10) \AA$, $b=14.91530(10) \AA$, and $c=21.10870(10) \AA$ (Table 1). The unit cell volume is 3620.50(4) $\AA^{3}$ with $Z=8$, and one molecule as asymmetric unit. The structure comprised three rings connected with the s-triazine core, which are the aminophenyl, pyrazolyl, and morpholine moieties. The morpholine moiety occurred in the chair form and the mean plane passing through the s-triazine core makes angles of 17.27 and $14.71^{\circ}$ with the phenyl and pyrazolyl moieties, respectively. Selected bond lengths and angles are listed in Table 2.
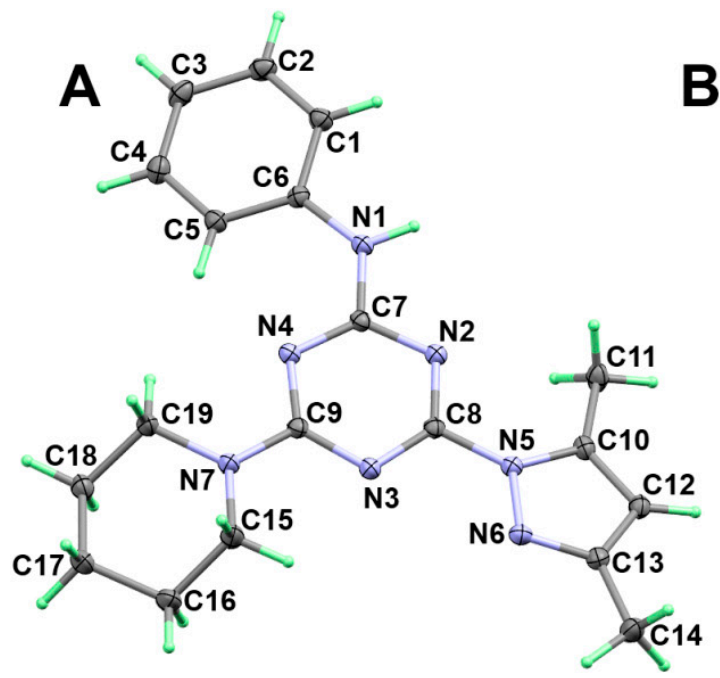

B
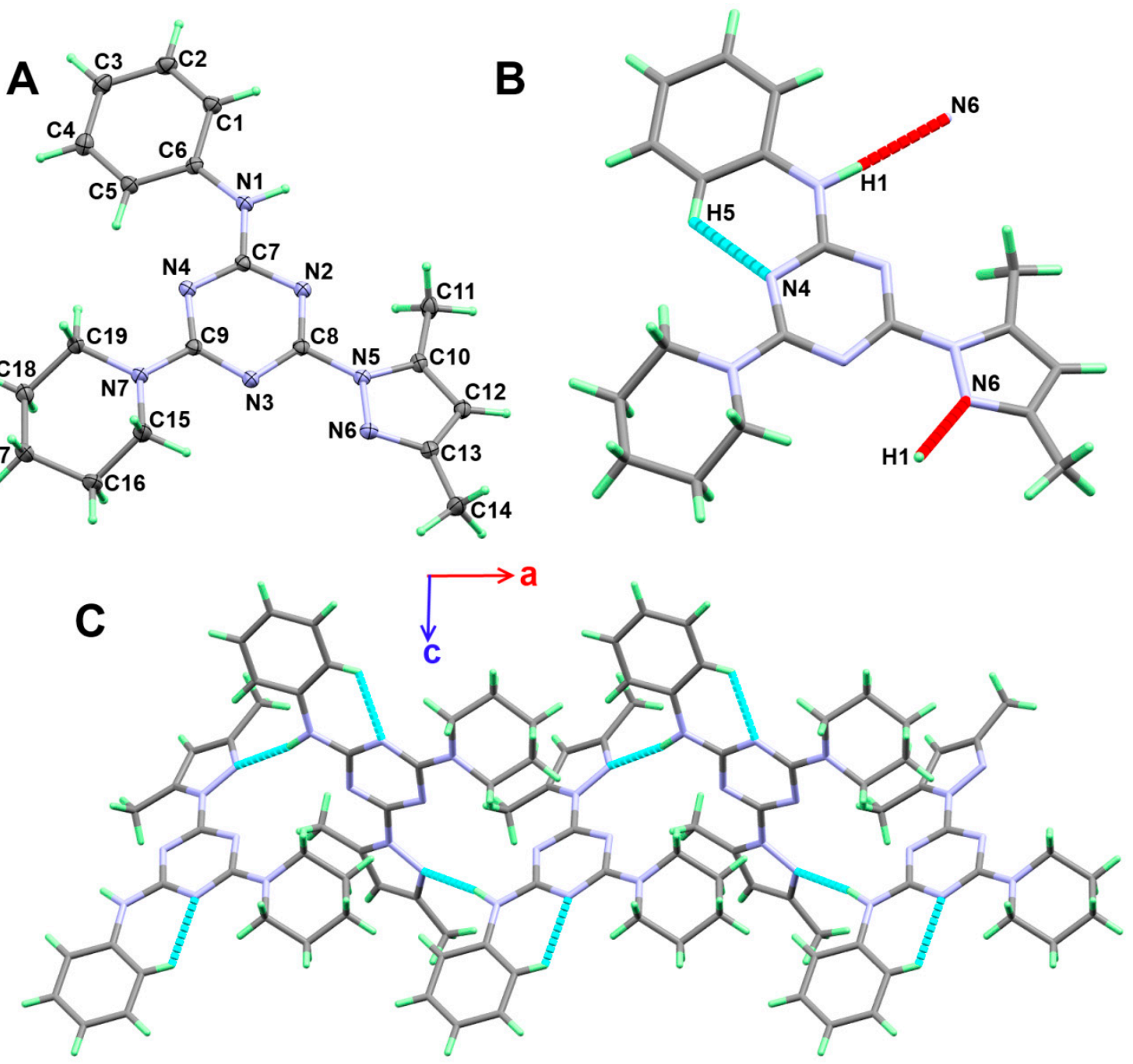

Figure 2. (A) Atom numbering and thermal ellipsoids at 30\% probability level (B) hydrogen bond contacts (C) and molecular packing along ac plane for $\mathbf{5 a}$.

The molecular structure of $\mathbf{5 a}$ is stabilized by $\mathrm{C}-\mathrm{H} \ldots \mathrm{N}$ intramolecular hydrogen bond between the one $\mathrm{C}-\mathrm{H}$ bond from the phenyl moiety as hydrogen bond donor and the neighbouring nitrogen atom from the s-triazine core. The donor-acceptor distance of the C-H ... N intramolecular hydrogen bond is 2.9366(13) $\AA$. The intramolecular C-H . . N N and the intermolecular $\mathrm{N}-\mathrm{H} \ldots \mathrm{N}$ hydrogen bond contacts are shown in Figure 2B as turquoise and red dotted lines, respectively. Viewing of the supramolecular structure of $\mathbf{5 a}$ is shown in Figure 2C, while the hydrogen bond parameters are depicted in Table 3. 
Table 2. Selected bond lengths $[\AA]$ and angles $\left[{ }^{\circ}\right]$ for $\mathbf{5 a}$ and $\mathbf{5 b}$.

\begin{tabular}{|c|c|c|c|}
\hline Atoms & Distance & Atoms & Distance \\
\hline & $5 a$ & & $5 b$ \\
\hline N1-C7 & $1.3611(12)$ & Br1-C3 & $1.9072(17)$ \\
\hline N1-C6 & $1.4072(13)$ & N1-C7 & $1.355(2)$ \\
\hline $\mathrm{N} 2-\mathrm{C} 8$ & $1.3230(13)$ & N1-C6 & $1.411(2)$ \\
\hline N2-C7 & $1.3508(13)$ & N2-C7 & $1.328(2)$ \\
\hline N3-C8 & $1.3242(13)$ & N2-C8 & $1.348(2)$ \\
\hline N3-C9 & $1.3552(13)$ & N3-C8 & $1.341(2)$ \\
\hline N4-C7 & $1.3310(12)$ & N3-C13 & $1.464(2)$ \\
\hline N4-C9 & $1.3551(12)$ & N3-C9 & $1.464(2)$ \\
\hline N5-N6 & $1.3770(11)$ & N4-C14 & $1.324(2)$ \\
\hline N5-C10 & $1.3841(12)$ & $\mathrm{N} 4-\mathrm{C} 8$ & $1.360(2)$ \\
\hline N5-C8 & $1.4082(12)$ & N5-C14 & $1.328(2)$ \\
\hline N6-C13 & $1.3218(13)$ & N5-C7 & $1.360(2)$ \\
\hline N7-C9 & $1.3483(13)$ & N6-N7 & $1.3772(19)$ \\
\hline N7-C19 & $1.4653(13)$ & N6-C15 & $1.388(2)$ \\
\hline N7-C15 & $1.4660(13)$ & N6-C14 & $1.404(2)$ \\
\hline Atoms & Angle & Atoms & Angle \\
\hline C7-N1-C6 & $130.29(8)$ & C7-N1-C6 & $127.70(14)$ \\
\hline C8-N2-C7 & $113.12(8)$ & C7-N2-C8 & $114.69(14)$ \\
\hline C8-N3-C9 & $112.94(8)$ & C8-N3-C13 & $122.58(14)$ \\
\hline C7-N4-C9 & $114.25(8)$ & C8-N3-C9 & $122.28(14)$ \\
\hline N6-N5-C10 & 111.63(8) & C13-N3-C9 & $114.33(13)$ \\
\hline N6-N5-C8 & $119.98(8)$ & C14-N4-C8 & $113.38(14)$ \\
\hline C10-N5-C8 & $128.25(8)$ & C14-N5-C7 & $112.51(13)$ \\
\hline C13-N6-N5 & 104.77(8) & N7-N6-C15 & 111.75(13) \\
\hline C9-N7-C19 & $122.30(8)$ & N7-N6-C14 & $118.27(13)$ \\
\hline C9-N7-C15 & $121.50(8)$ & C15-N6-C14 & $129.96(14)$ \\
\hline C19-N7-C15 & $115.29(8)$ & C18-N7-N6 & 104.93(13) \\
\hline
\end{tabular}

Table 3. Hydrogen bonds for $5 \mathbf{a}$ and $5 \mathbf{b}\left[\AA\right.$ and $\left.^{\circ}\right]$.

\begin{tabular}{|c|c|c|c|c|}
\hline D-H . . A & d(D-H) & $\mathrm{d}(\mathbf{H} \ldots \mathbf{A})$ & $d(D \ldots A)$ & $<$ (DHA) \\
\hline \multicolumn{5}{|c|}{$5 \mathbf{a}$} \\
\hline N1-H1 . . N6\#1 & $0.894(15)$ & $2.219(15)$ & $3.0995(12)$ & $167.9(13)$ \\
\hline C5-H5 ... N4 & 0.95 & 2.33 & $2.9366(13)$ & 121.3 \\
\hline \multicolumn{5}{|l|}{$\# 1 x-1 / 2, y,-z+3 / 2$} \\
\hline \multicolumn{5}{|c|}{$5 b$} \\
\hline C5-H5 ... N2 & 0.95 & 2.39 & $2.887(2)$ & 111.9 \\
\hline C5b-H5b ... N2B & 0.95 & 2.25 & $2.870(2)$ & 121.9 \\
\hline C9B-H9BA ... N6B\#1 & 0.99 & 2.59 & $3.355(2)$ & 134.4 \\
\hline C9B-H9BA . . . N7B\#1 & 0.99 & 2.54 & $3.501(2)$ & 165 \\
\hline C10B-H10C ... Br1B\#2 & 0.99 & 2.97 & $3.7507(17)$ & 136.7 \\
\hline N1B-H1B ... N5 & $0.85(2)$ & $2.21(2)$ & $3.0621(19)$ & $176(2)$ \\
\hline N1-H1 . . N4B & $0.92(2)$ & $2.25(2)$ & $3.1452(18)$ & $165(2)$ \\
\hline N1-H1 ... N7B & $0.92(2)$ & $2.43(2)$ & $3.040(2)$ & $123.9(19)$ \\
\hline \multicolumn{5}{|c|}{$\# 1-x+1,-y+1,-z+1 \# 2-x+1, y,-z+1 / 2$} \\
\hline
\end{tabular}

On the other hand, compound $5 \mathbf{b}$ in the orthorhombic system and $\mathrm{Pbcn}$ space group with unit cell parameters of $a=37.4570(3) \AA, b=8.62930(10) \AA$, and $c=24.8053(2) \AA$ (Table 1). The unit cell volume is $8017.76(13) \AA^{3}$ with $Z=16$ and two molecules as an asymmetric unit. The structure of the two molecular units of $5 \mathbf{b}$ is shown in Figure 3A,B. 
Moreover, the structure comprised three rings connected with the s-triazine core, which are the p-bromoaminophenyl, pyrazolyl, and morpholine moieties. The morpholine moiety also occurred in the chair form. In this case, the twists of the phenyl ring moiety from the mean plane passing through the s-triazine core are found more than in $5 \mathbf{a}$ in unit $\mathrm{A}\left(29.44^{\circ}\right)$ and less in unit $\mathrm{B}\left(10.46^{\circ}\right)$. The corresponding values for the pyrazolyl moiety are 8.22 and $7.17^{\circ}$, respectively.
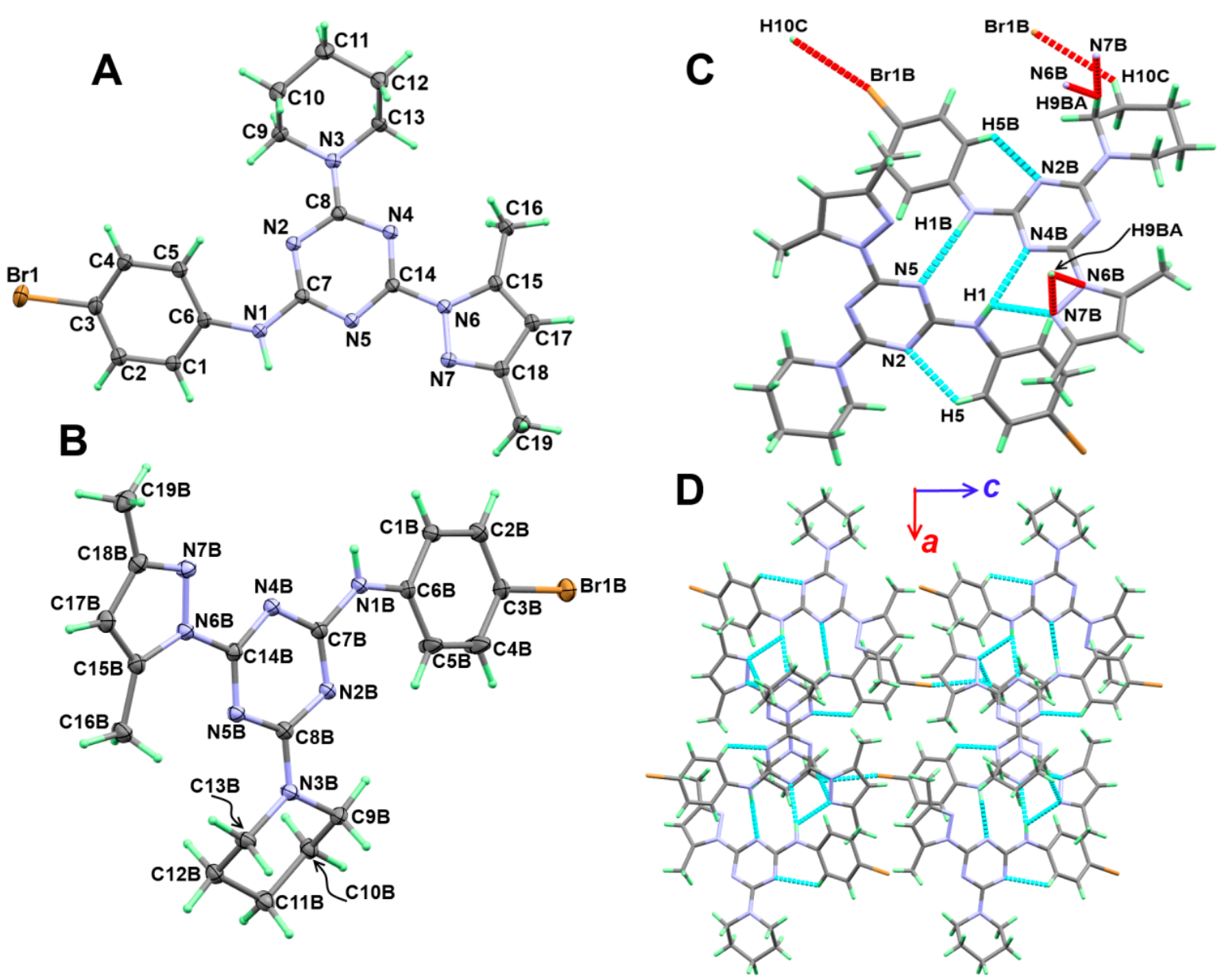

Figure 3. (A,B) Atom numbering and thermal ellipsoids at 30\% probability level, (C) hydrogen bond contacts (D) and molecular packing along ac plane for $5 \mathbf{b}$.

Moreover, the molecular structure of the two units in $\mathbf{5 b}$ is stabilized by slightly shorter C-H ... N intramolecular interactions, with a donor-acceptor distance of 2.887(2) and 2.870(2) $\AA$ for C5-H5 . . N N2 and C5b-H5b . . N2B interactions, respectively. The packing of this compound is controlled by a number of $\mathrm{C}-\mathrm{H} \ldots \mathrm{N}, \mathrm{N}-\mathrm{H} \ldots \mathrm{N}$ and $\mathrm{C}-\mathrm{H} \ldots \mathrm{Br}$ hydrogen bonds (Table 3 and Figure 3C). Viewing of the packing scheme of $\mathbf{5 b}$ is shown in Figure 3D.

\subsection{Analysis of Molecular Packing}

The intermolecular interactions play important role in the crystal stability. In this regard, the different contacts in the crystal structures of $\mathbf{5 a}$ and $\mathbf{5 b}$ were analysed with the aid of Hirshfeld calculations. These contacts and their percentages are summarized in Figure 4. For 5a, the structure contains three elements which are $\mathrm{C}, \mathrm{H}$, and N. Hence, the $\mathrm{C} \ldots \mathrm{C}, \mathrm{C} \ldots \mathrm{H}, \mathrm{C} \ldots \mathrm{N}, \mathrm{H} \ldots \mathrm{H}, \mathrm{N} \ldots \mathrm{H}$ and $\mathrm{N} \ldots \mathrm{N}$ are the only possible contacts. Of these interactions, only five contacts occurred, which are $\mathrm{H} \ldots \mathrm{C}, \mathrm{H} \ldots \mathrm{H}$ and $\mathrm{N} \ldots \mathrm{H}$. Their percentages are 22.2, 58.4, and $19.0 \%$, respectively. Hence, the $\mathrm{H} \ldots \mathrm{H}, \mathrm{N} \ldots \mathrm{H}$ and $\mathrm{H}$... C contacts are the most dominant. Among these contacts, the N . . H and H . . C are the most important, based on the $d_{\text {norm }}$ map shown in Figure 5 . These are the only 
contacts which appeared as red regions, indicating shorter distances than the van der Waals (vdWs) radii sum of the interacting atoms.

$\square 5 a 5 b$ (unit A) $\quad \square b$ (unit B)

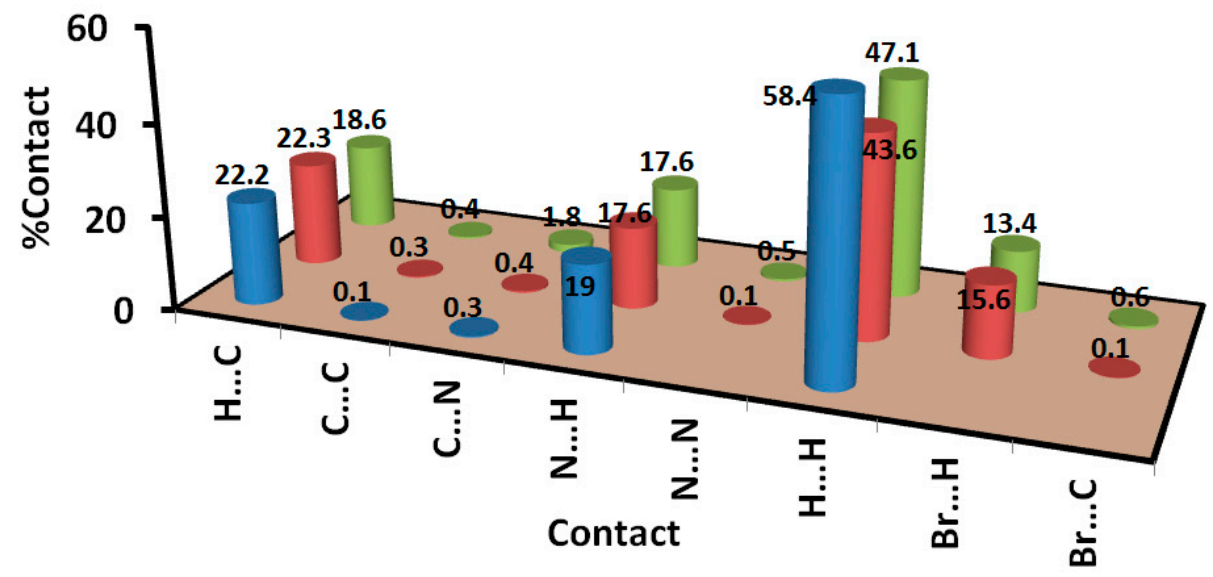

Figure 4. The percentages of all possible intermolecular interactions in the studied systems.
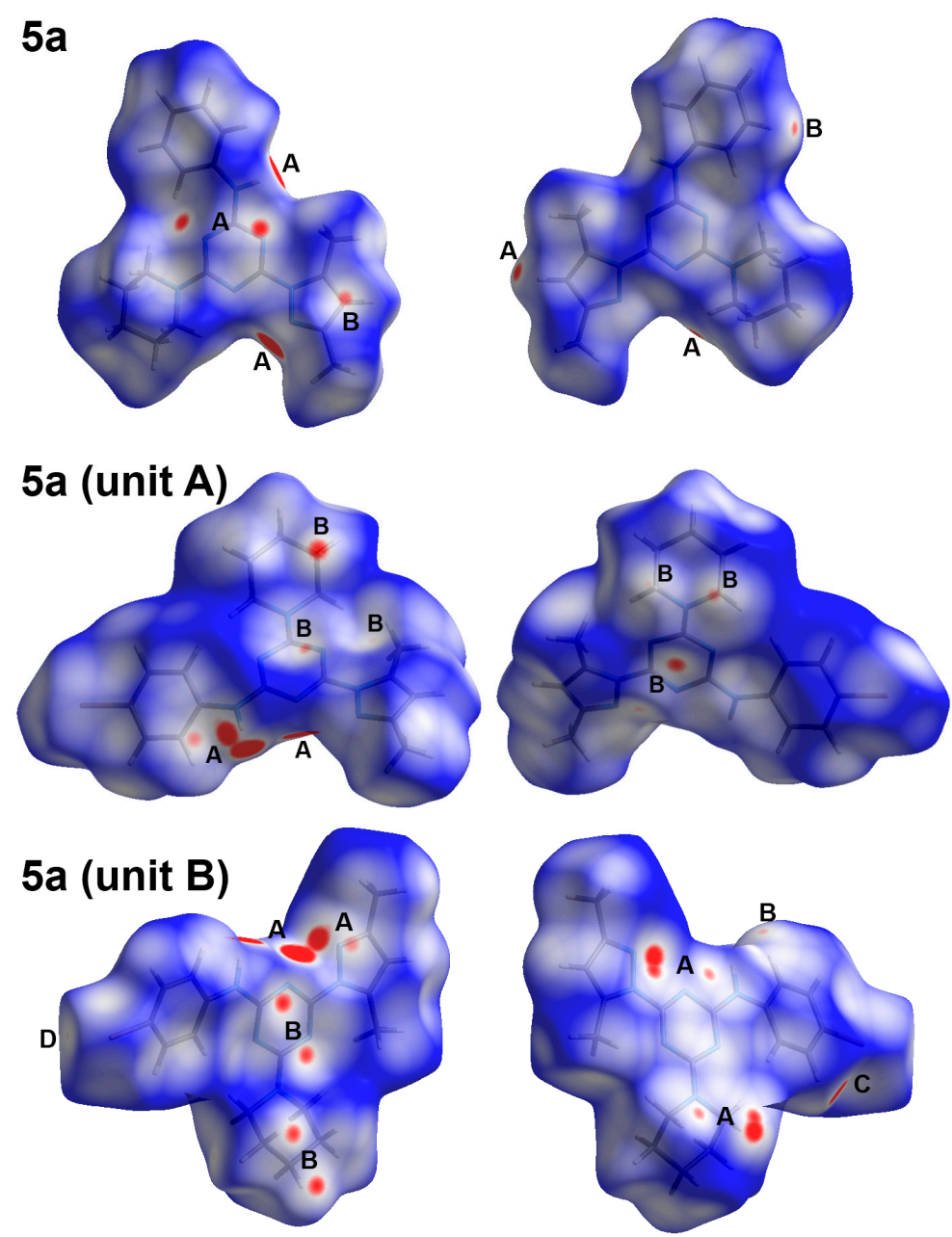

Figure 5. The $d_{\text {norm }}$ maps of the studied systems showing the most important interactions: (A) N ... H, (B) H .. C, (C) H .. H and (D) Br ... H.

Another piece of evidence which confirms the importance of these contacts is the sharp spikes that appeared in the decomposed fingerprint plots of the $\mathrm{N} \ldots \mathrm{H}$ and $\mathrm{H} \ldots \mathrm{C}$ 
contacts. The sharp spikes indicate significantly short interactions (Figure 6). Summary of the short $\mathrm{N} \ldots \mathrm{H}$ and $\mathrm{H} \ldots \mathrm{C}$ interactions having distances smaller than the vdWs radii sum of the interacting atoms are listed in Table 4.
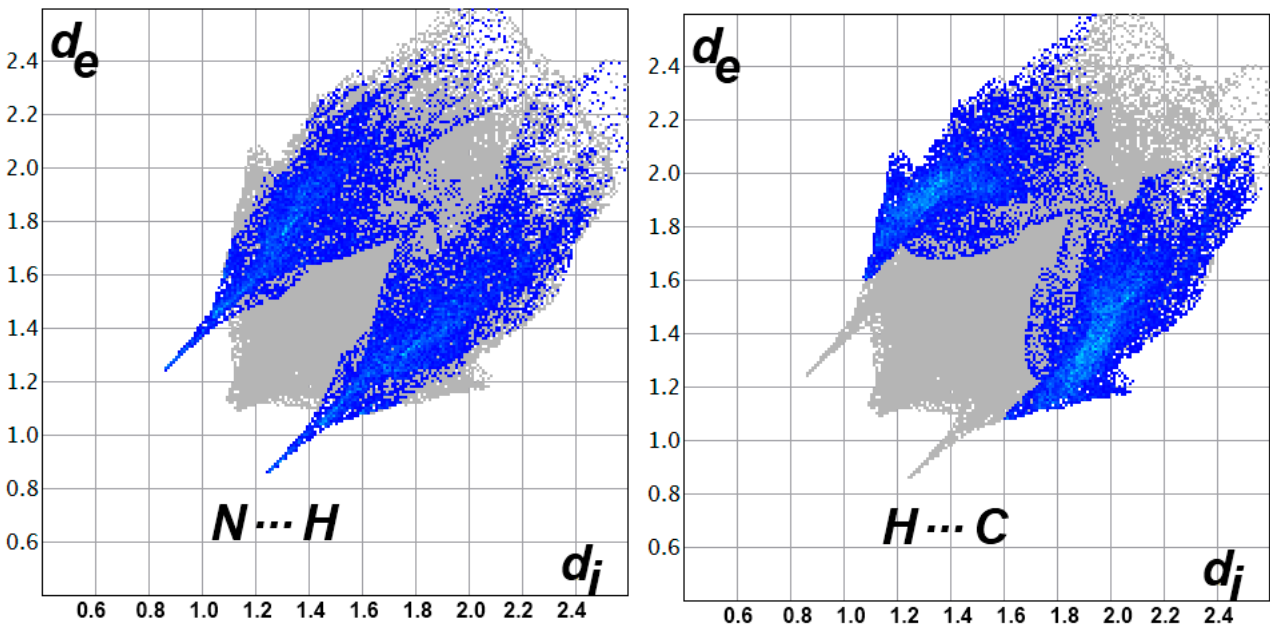

Figure 6. Decomposed fingerprint plots for the short intermolecular interactions in $\mathbf{5 a}$.

Table 4. All short intermolecular interactions in the studied systems.

\begin{tabular}{|c|c|c|c|c|c|}
\hline Contact & Distance & Contact & Distance & Contact & Distance \\
\hline \multicolumn{2}{|c|}{$5 a$} & \multicolumn{4}{|c|}{$5 b$} \\
\hline N6 ... H1 & 2.108 & H13A . . C15 & 2.763 & N7 ... H1B & 2.627 \\
\hline N4 ... H12 & 2.476 & H9B ... C14 & 2.715 & N6B ... H9BA & 2.523 \\
\hline $\mathrm{N} 2 \ldots \mathrm{H} 15 \mathrm{~b}$ & 2.492 & H1AB . . C C14 & 2.740 & N7B ... H9BA & 2.446 \\
\hline \multirow[t]{4}{*}{ H4 . . C12 } & 2.687 & $\mathrm{H} 12 \mathrm{~B} \ldots \mathrm{C} 8$ & 2.632 & N4B ... H13D & 2.561 \\
\hline & & N7B . . H1 & 2.380 & Н4B ... H4B & 1.795 \\
\hline & & N4B ... H1 & 2.162 & Br1B ... H10C & 2.902 \\
\hline & & N5 ... H1B & 2.055 & & \\
\hline
\end{tabular}

The structure of $\mathbf{5 b}$ comprised an extra $\mathrm{Br}$ atom attached at the 4-position of the phenyl ring. Hence, more intermolecular interactions were detected in this compound (Figure 4). Since there are two different molecular units per asymmetric formula, there are two sets of results for this molecular system. Based on Hirshfeld calculations, and similar to $5 \mathrm{a}$, the $\mathrm{H} \ldots \mathrm{H}, \mathrm{N} \ldots \mathrm{H}$ and $\mathrm{H} \ldots \mathrm{C}$ are the most dominant contacts. In addition, there is significant amount of $\mathrm{Br}$. . H contacts. The H12B . . C 8 (2.632 $\AA$ ), N5 ... H1B (2.055 $)$, H4B . . H4B (1.795 $)$, and Br1B . . H10C (2.902 $\AA$ ) are the shortest contacts, respectively. All four of these contacts appeared as a red region in the $d_{\text {norm }}$ map (Figure 5). An important difference between the two molecular units of $\mathbf{5 b}$ is that the $\mathrm{Br} \ldots \mathrm{H}$ and $\mathrm{H} \ldots \mathrm{H}$ interactions are more important in the molecular unit with the letter $\mathrm{B}$ in the atom numbering than the other unit. Moreover, the percentages of the $\mathrm{H} \ldots \mathrm{H}$, $\mathrm{Br} \ldots \mathrm{H}$, and $\mathrm{H} \ldots \mathrm{C}$ contacts are also different in both units (Figure 7).

\section{DFT studies \\ Optimized Geometry}

The calculated optimized structures of $\mathbf{5 a}$ and $\mathbf{5 b}$ agreed very well with the reported X-ray structures, as indicated from the excellent matching between them (Figure 8) as well as the excellent correlations between the calculated and experimental bond distances and angles (Figure 9). In addition, the differences between the calculated and experimental bond distances are found to not exceed $0.01 \AA$ (Table S1; Supplementary data). Moreover, the correlation coefficients $\left(R^{2}\right)$ are calculated to be very close to unity (Figure 9). Some higher deviations occurred in the bond angles, which could be attributed to the relaxation of the molecular structure as a consequence of the geometry optimization in the absence of the 
crystal packing effect. Generally, the differences between the calculated and experimental bond angles did not exceed $2.8^{\circ}$ (Table S1; Supplementary data).

\section{$5 b$ (unit A)}
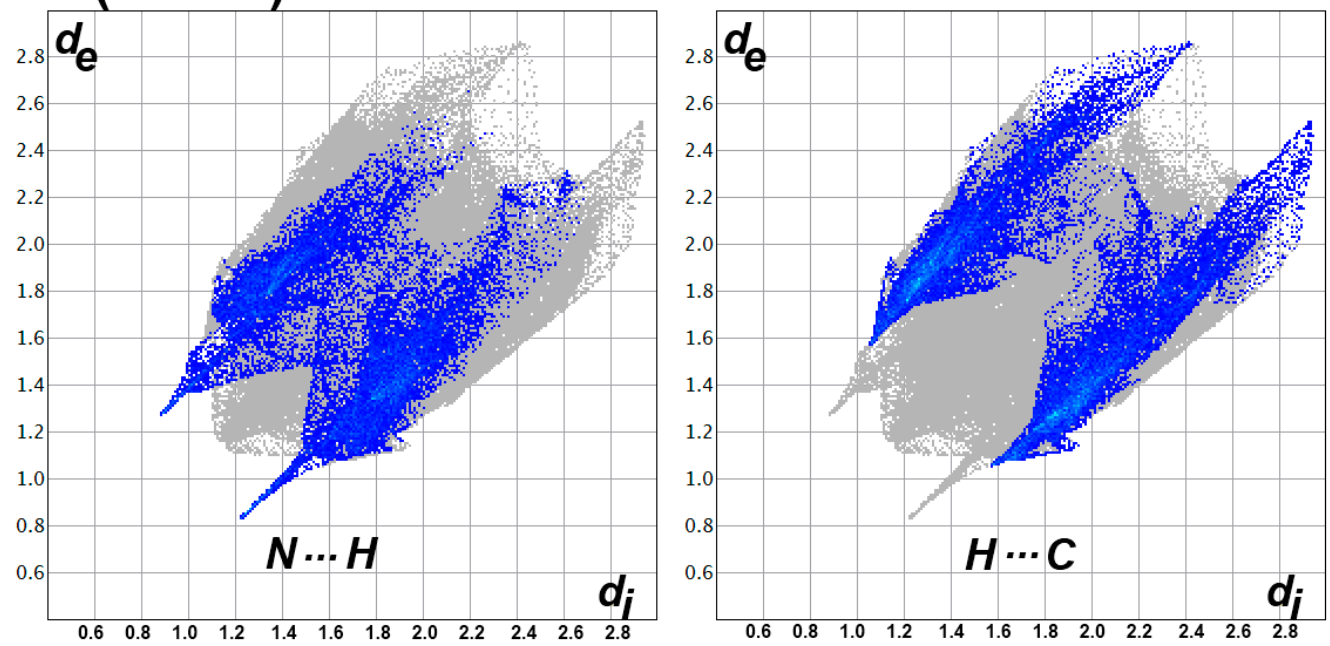

\section{$5 b$ (unit B)}
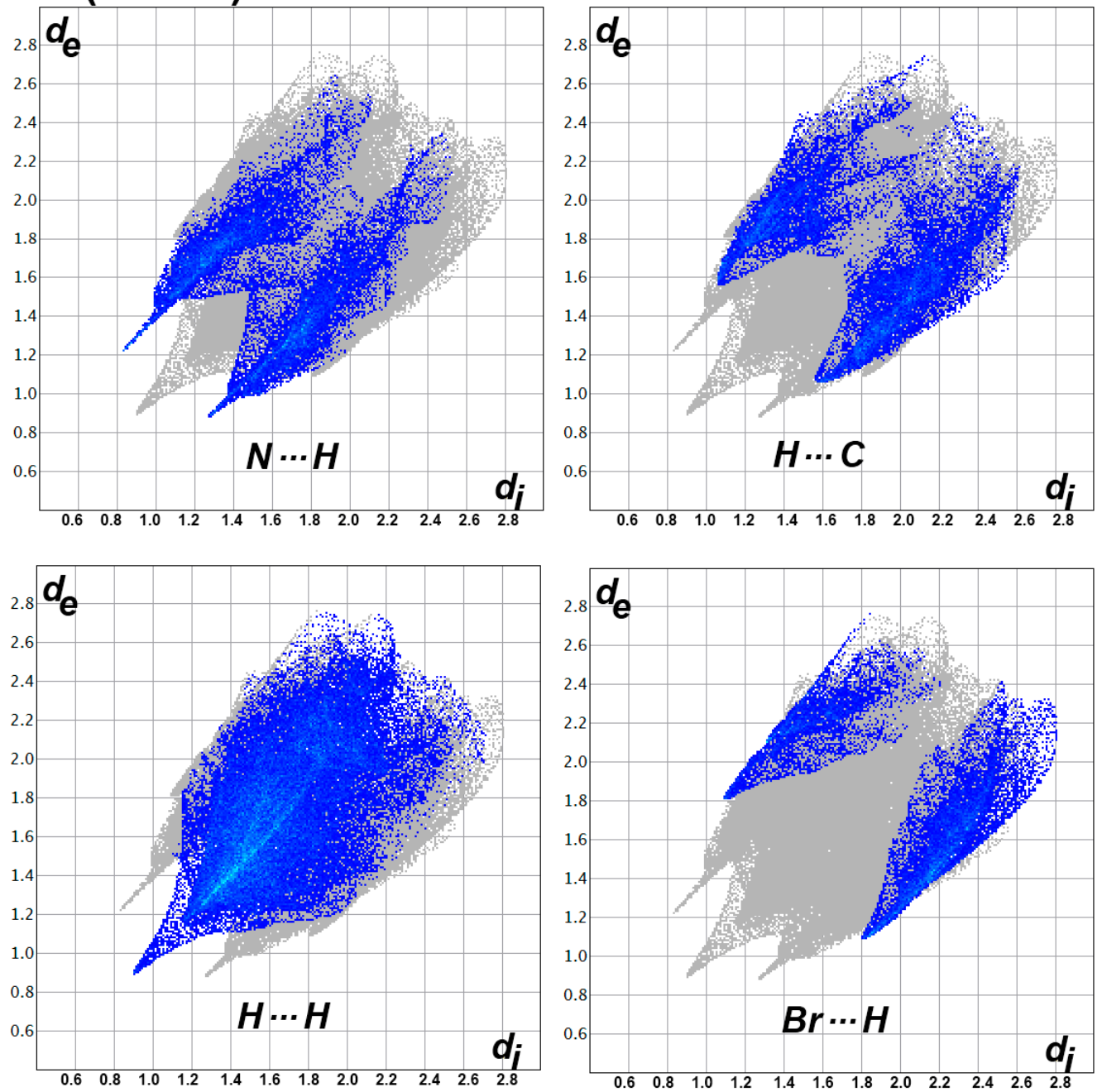

Figure 7. Decomposed fingerprint plots for the short intermolecular interactions in $\mathbf{5 b}$. 

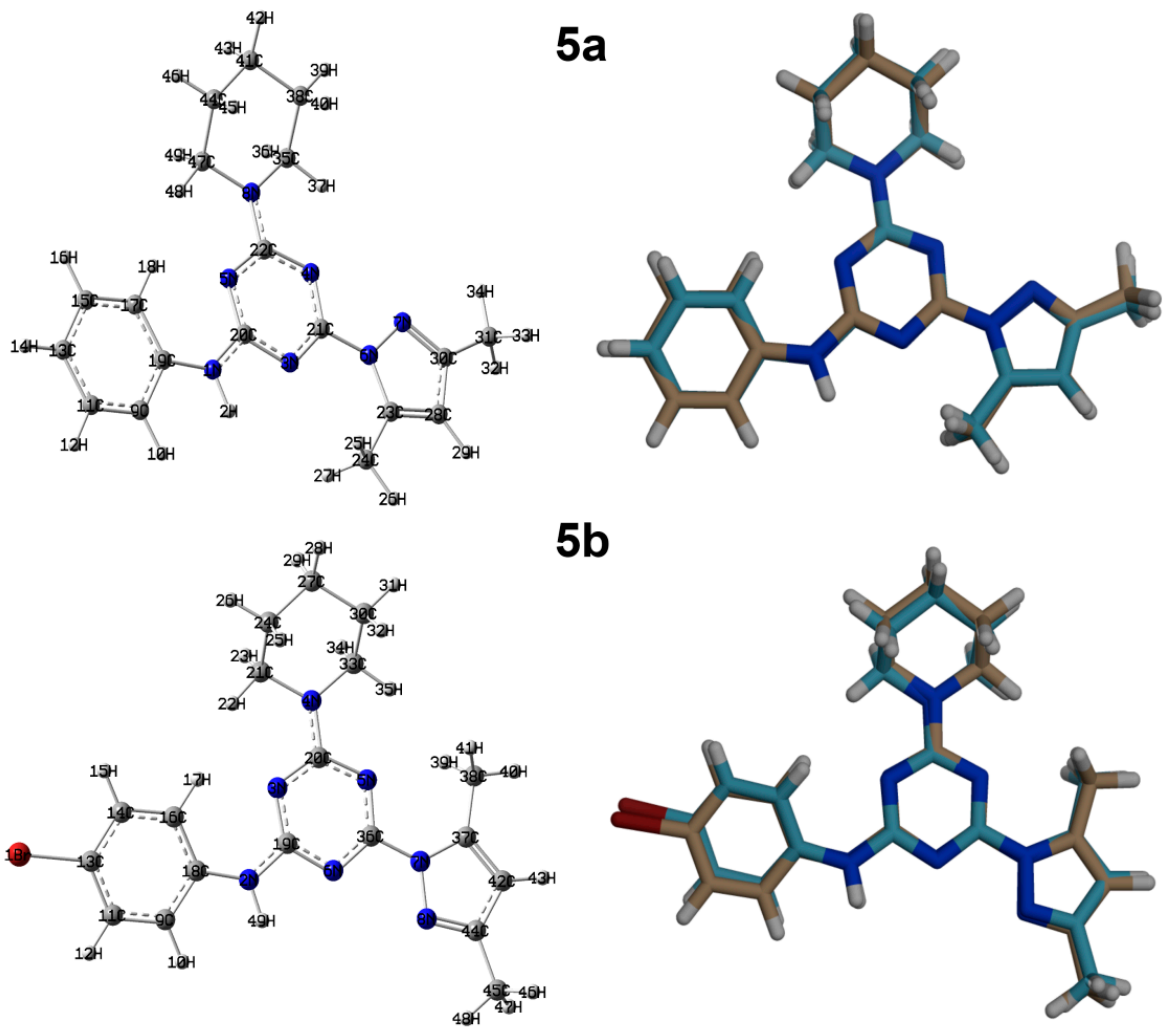

$5 b$

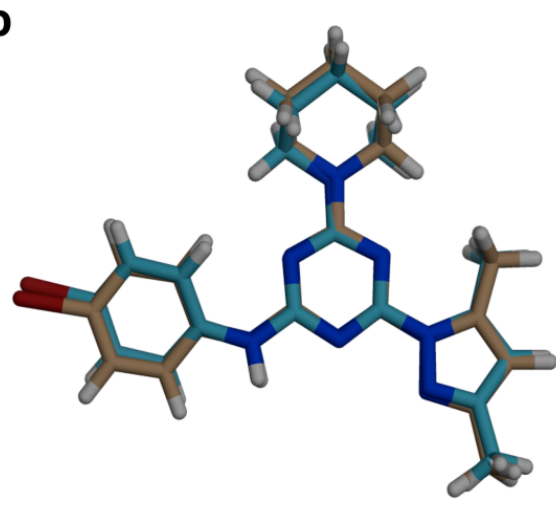

Figure 8. Optimized structures (left) and overlay of the optimized with experimental structures (right) for the studied compounds.
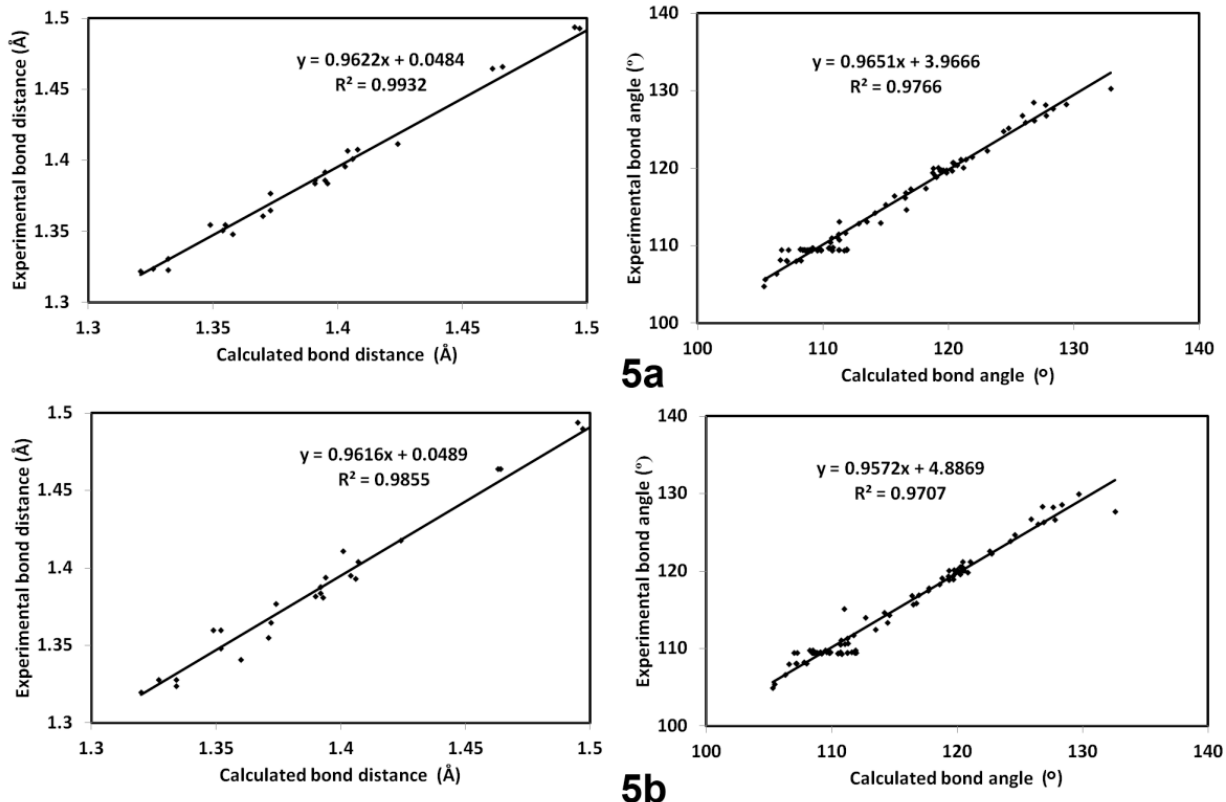

Figure 9. The straight line correlations between the calculated and experimental geometric parameters (Table S1; Supplementary data).

Both of the studied systems comprised CHN backbone and differ only in the substituent attached to the phenyl moiety. Graphical presentations of the natural charges at the different atomic sites are shown in Figure 10. The $\mathrm{N}$ atoms of the triazine core and the aniline moiety are more electronegative than the $\mathrm{N}$-atoms of pyrazolyl and piperidinyl moieties in both compounds (Table S2; Supplementary data). The C-atoms of the $\mathrm{CH}_{3}$ groups are the most electronegative $\mathrm{C}$-sites. In contrast, all $\mathrm{C}$-atoms bonded to nitrogen 
have high positive charge. Of $\mathrm{C}$-atoms, the $s$-triazine $\mathrm{C}$-atoms are the most electropositive, as these carbons found located between two nitrogen sites in the s-triazine moiety. Moreover, all hydrogen sites have a positive charge where the $\mathrm{NH}$ protons are the most positively charged. The natural charge values are calculated to be 0.434 and 0.443 e for $5 \mathbf{a}$ and $\mathbf{5 b}$, respectively. In the right part of Figure 11, the molecular electrostatic potential (MEP) maps of both compounds are shown. The red regions are related to the atomic sites with high electron density, while the blue regions are related to the atomic sites with lowest electron density, which represents the most possible sites as hydrogen bond acceptor and donors, respectively.
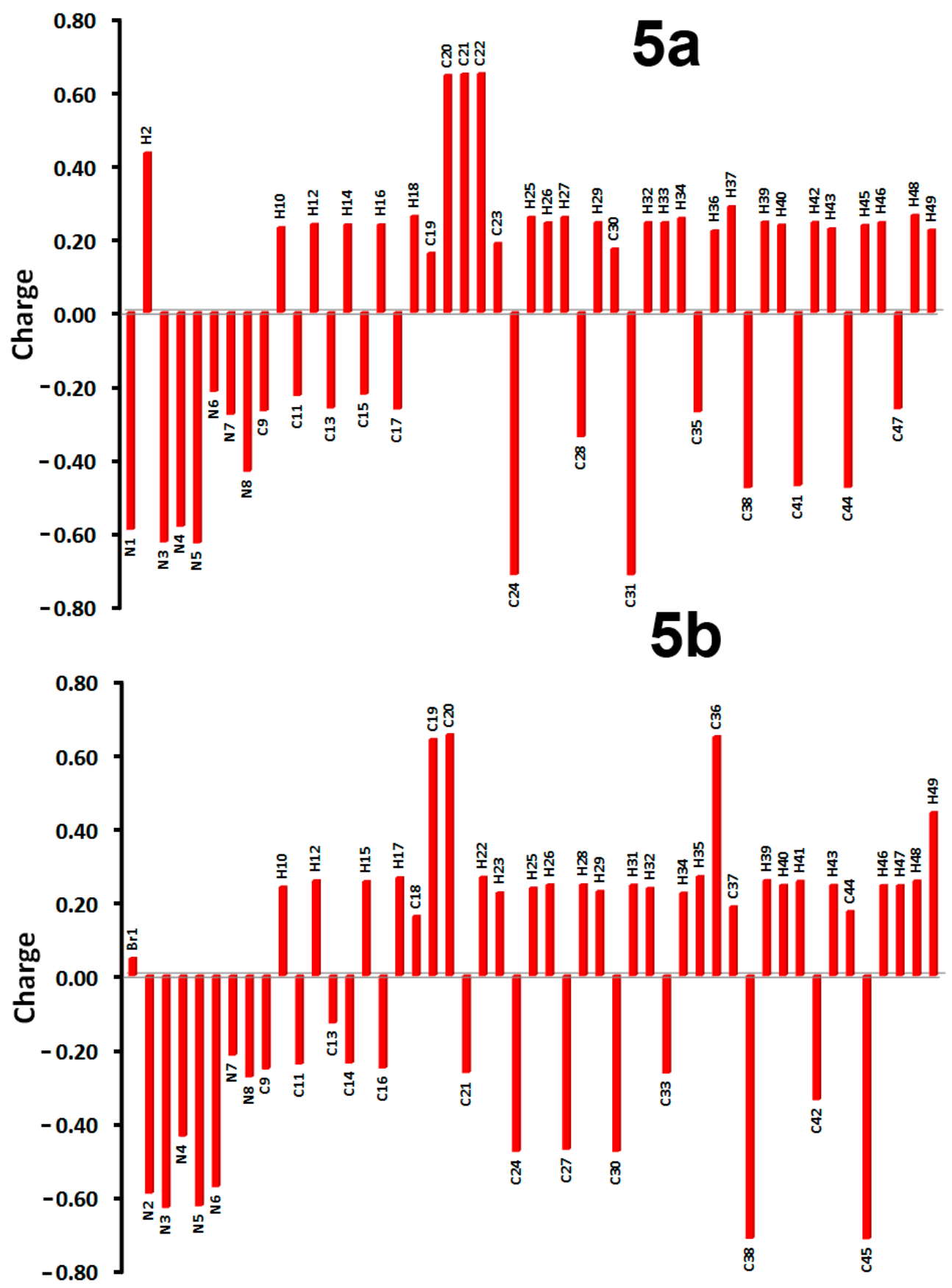

Figure 10. Natural charge populations at the different atomic sites for $\mathbf{5 a}$ and $\mathbf{5 b}$. 

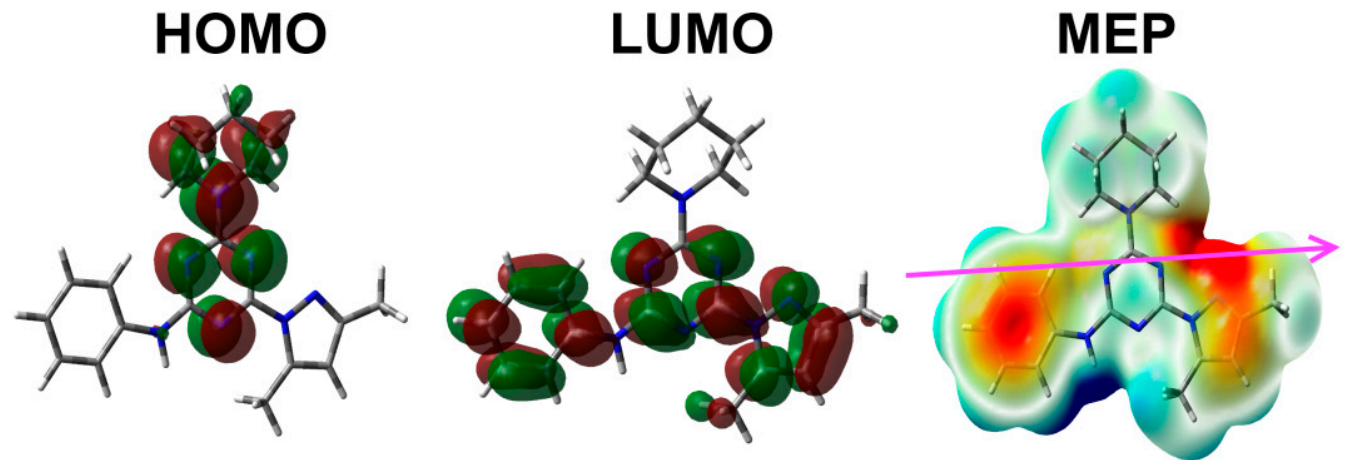

$5 a$
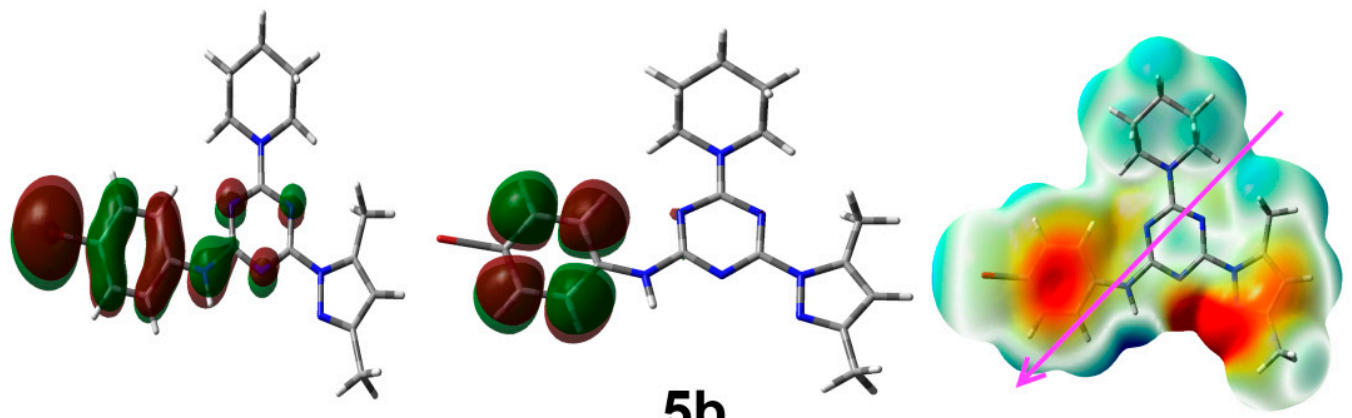

Figure 11. The MEP, HOMO, and LUMO for the studied compounds. In MEP, the red and blue colors indicate the most negative and most positive regions, respectively.

Both compounds are polar molecules with net dipole moment of 1.018 and 4.249 Debye for $\mathbf{5 a}$ and $\mathbf{5 b}$, respectively. The compound with bromo substituent at the phenyl ring $(\mathbf{5 b})$ has a higher polarity than the one with an unsubstituted phenyl ring (5a). The substituent has also a great effect on the direction of the dipole moment vector, as can be seen from Figure 11 (left part).

Moreover, the substituent at the phenyl moiety has a direct impact on the distribution of the HOMO and LUMO levels on the studied molecular systems. In case of $\mathbf{5 a}$, the HOMO level is mainly located over the s-triazine core and the piperidinyl fragment, while the LUMO is distributed over the $\pi$-system of the s-triazine core, phenyl, and pyrazolyl moieties. In this case, the HOMO-LUMO energy gap is calculated to be $4.917 \mathrm{eV}$. On the other hand, the HOMO and LUMO are mainly located over the phenyl moiety in case of $\mathbf{5 b}$. The HOMO has some distribution over the s-triazine core, where the HOMO-LUMO energy gap is slightly less in $\mathbf{5 b}(4.804 \mathrm{eV})$ compared to $\mathbf{5 a}$.

\subsection{Electronic Reactivity Parameters}

The HOMO and LUMO energies are presented in Table 5. The molecular reactivity parameters such as electrophilicity index $\left(\omega=\mu^{2} / 2 \eta\right)$, electron affinity $\left(A=-E_{\text {LUMO }}\right)$, ionization potential $\left(\mathrm{I}=-\mathrm{E}_{\mathrm{HOMO}}\right)$, hardness $(\eta=(\mathrm{I}-\mathrm{A}) / 2)$, as well as chemical potential $(\mu=-(\mathrm{I}+\mathrm{A}) / 2)$ reactivity indices, were calculated based on the HOMO and LUMO energies [41-44], and the results are also listed in Table 5. The ionization potential and electron affinity values of $\mathbf{5 b}$ are lower than $\mathbf{5 a}$. In contrast, the chemical hardness, chemical potential, and electrophilicity index have higher values for $\mathbf{5 b}$ than $\mathbf{5 a}$. 
Table 5. Reactivity parameters in $\mathrm{eV}$ of the studied compounds.

\begin{tabular}{ccc}
\hline Parameter & $\mathbf{5 a}$ & $\mathbf{5 b}$ \\
\hline E $_{\text {HOMO }}$ & -5.6856 & -5.7166 \\
E $_{\text {LUMO }}$ & -0.7690 & -0.9129 \\
$\mathrm{I}$ & 5.6856 & 5.7166 \\
$\mathrm{~A}$ & 0.7690 & 0.9129 \\
$\eta$ & 4.9166 & 4.8037 \\
$\mu$ & -3.2273 & -3.3148 \\
$\omega$ & 1.0592 & 1.1437 \\
\hline
\end{tabular}

\subsection{NBO Analysis}

The electron conjugation process has a great impact on the stability of molecular system $[45,46]$. In this regard, the different electron delocalization processes and their stabilization energies $\left(\mathrm{E}^{(2)}\right)$ are summarized in Table 6. The $\sigma \rightarrow \sigma^{*}, \pi \rightarrow \pi^{*}, \mathrm{n} \rightarrow \pi^{*}$ and $\mathrm{n} \rightarrow \sigma^{*}$ intramolecular charge transfer (IMCT) processes stabilized the system up to $6.37,47.40,72.58$, and $13.20 \mathrm{kcal} / \mathrm{mol}$ for the $\mathrm{BD}(1) \mathrm{C} 28-\mathrm{C} 30 \rightarrow \mathrm{BD}^{*}(1) \mathrm{C} 23-\mathrm{C} 24, \mathrm{BD}(2) \mathrm{N} 5-$ $\mathrm{C} 22 \rightarrow \mathrm{BD}^{*}(2) \mathrm{N} 3-\mathrm{C} 20, \mathrm{LP}(1) \mathrm{N} 8 \rightarrow \mathrm{BD}^{*}(2) \mathrm{N} 5-\mathrm{C} 22$ and $\mathrm{LP}(1) \mathrm{N} 5 \rightarrow \mathrm{BD}^{*}(1) \mathrm{N} 3-\mathrm{C} 20$ in $\mathbf{5 a}$, respectively. The corresponding values for $5 \mathbf{b}$ are $6.39,44.78,70.72$, and $12.99 \mathrm{kcal} / \mathrm{mol}$ for the $\mathrm{BD}(1) \mathrm{C} 42-\mathrm{C} 44 \rightarrow \mathrm{BD}^{*}(1) \mathrm{C} 37-\mathrm{C} 38, \mathrm{BD}(2) \mathrm{N} 5-\mathrm{C} 20 \rightarrow \mathrm{BD}^{*}(2) \mathrm{N} 6-\mathrm{C} 36, \mathrm{LP}(1) \mathrm{N} 4 \rightarrow \mathrm{BD}^{*}(2) \mathrm{N} 5-\mathrm{C} 20$ and $\mathrm{LP}(1) \mathrm{N} 6 \rightarrow \mathrm{BD}^{*}(1) \mathrm{N} 3-\mathrm{C} 19$, respectively.

\subsection{NMR Spectra}

The calculated HNMR and CNMR chemical shifts by empolying GIAO method and final data are listed in Supplementary Materials in Tables S3 and S4. Figure 12 presented the correlations between computed NMR chemical shifts with experimental data. As we observed from the presented graphs, the correlation coefficients $\left(R^{2}\right)$ are high and close to 1 . The $\mathrm{R}^{2}$ values range from 0.93 to 0.94 , indicating the close agreement between the computed and experimental results.
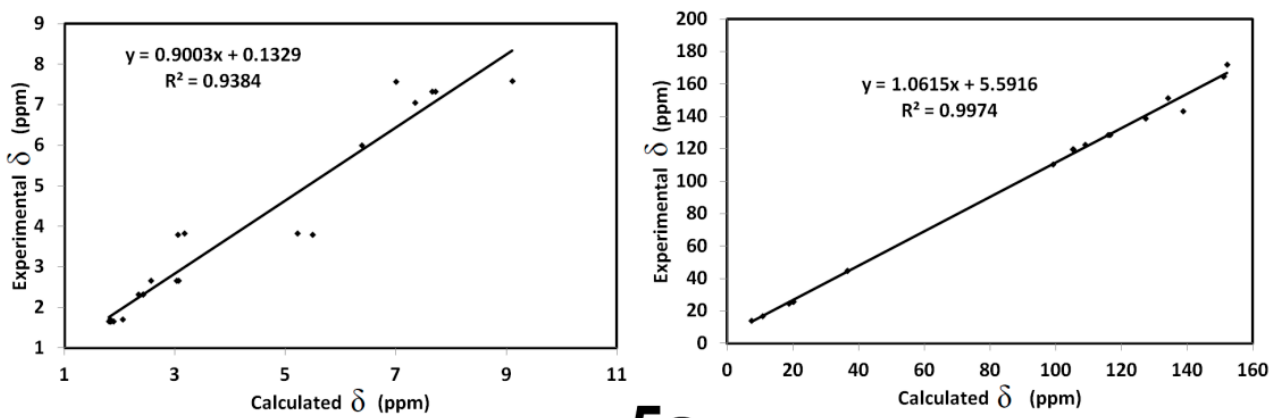

\section{$5 a$}
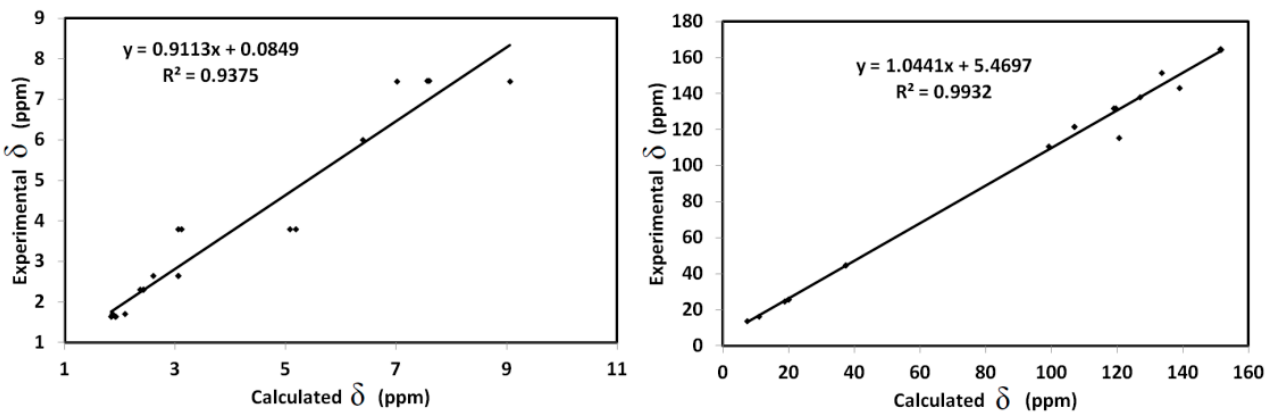

\section{$5 b$}

Figure 12. ${ }^{1} \mathrm{H}$ and ${ }^{13} \mathrm{C}$ NMR correlations between the calculated and experimental data. 
Table 6. The $\mathrm{E}^{(2)}(\mathrm{kcal} / \mathrm{mol})$ values for the charge transfer interactions in $\mathbf{5 a}$ and $5 \mathbf{b}^{\mathrm{a}}$.

\begin{tabular}{|c|c|c|c|c|c|}
\hline Donor NBO & Acceptor NBO & $E^{(2)}$ & Donor NBO & Acceptor NBO & $E^{(2)}$ \\
\hline \multicolumn{3}{|c|}{$5 a$} & \multicolumn{3}{|c|}{$5 b$} \\
\hline \multicolumn{6}{|l|}{$\sigma \rightarrow \sigma^{*}$} \\
\hline BD(1)N3-C20 & $\mathrm{BD}^{*}(1) \mathrm{N} 6-\mathrm{C} 21$ & 5.72 & BD(1)N3-C19 & $\mathrm{BD}^{*}(1) \mathrm{N} 4-\mathrm{C} 20$ & 4.75 \\
\hline BD(1)N4-C21 & $\mathrm{BD}^{*}(1) \mathrm{N} 8-\mathrm{C} 22$ & 4.60 & BD(1)N3-C20 & $\mathrm{BD}^{*}(1) \mathrm{N} 2-\mathrm{C} 19$ & 5.55 \\
\hline BD(1)N5-C20 & BD*(1)N8-C22 & 4.71 & BD(1)N5-C20 & $\mathrm{BD}^{*}(1) \mathrm{N} 7-\mathrm{C} 36$ & 5.24 \\
\hline $\mathrm{BD}(1) \mathrm{N} 5-\mathrm{C} 22$ & BD*(1)N1-C20 & 5.68 & BD(1)N5-C36 & $\mathrm{BD}^{*}(1) \mathrm{N} 4-\mathrm{C} 20$ & 4.75 \\
\hline BD(1)N6-N7 & $\mathrm{BD}^{*}(1) \mathrm{C} 30-\mathrm{C} 31$ & 4.93 & BD(1)N6-C19 & $\mathrm{BD}^{*}(1) \mathrm{N} 7-\mathrm{C} 36$ & 6.05 \\
\hline $\mathrm{BD}(1) \mathrm{C} 15-\mathrm{C} 17$ & BD*(1)N1-C19 & 4.76 & $\mathrm{BD}(1) \mathrm{N} 6-\mathrm{C} 36$ & $\mathrm{BD}^{*}(1) \mathrm{N} 2-\mathrm{C} 19$ & 4.37 \\
\hline $\mathrm{BD}(1) \mathrm{C} 23-\mathrm{C} 28$ & BD*(1)N6-C21 & 4.89 & BD(1)N7-N8 & $\mathrm{BD}^{*}(1) \mathrm{C} 44-\mathrm{C} 45$ & 4.93 \\
\hline $\mathrm{BD}(1) \mathrm{C} 23-\mathrm{C} 28$ & $\mathrm{BD}^{*}(1) \mathrm{C} 30-\mathrm{C} 31$ & 5.08 & BD(1)C9-C11 & $\mathrm{BD}^{*}(1) \mathrm{Br} 1-\mathrm{C} 13$ & 4.83 \\
\hline \multirow[t]{4}{*}{$\mathrm{BD}(1) \mathrm{C} 28-\mathrm{C} 30$} & $\mathrm{BD}^{*}(1) \mathrm{C} 23-\mathrm{C} 24$ & 6.37 & $\mathrm{BD}(1) \mathrm{C} 14-\mathrm{C} 16$ & $\mathrm{BD}^{*}(1) \mathrm{Br} 1-\mathrm{C} 13$ & 4.87 \\
\hline & & & $\mathrm{BD}(1) \mathrm{C} 14-\mathrm{C} 16$ & $\mathrm{BD}^{*}(1) \mathrm{N} 2-\mathrm{C} 18$ & 4.49 \\
\hline & & & $\mathrm{BD}(1) \mathrm{C} 37-\mathrm{C} 42$ & $\mathrm{BD}^{*}(1) \mathrm{C} 44-\mathrm{C} 45$ & 5.06 \\
\hline & & & $\mathrm{BD}(1) \mathrm{C} 42-\mathrm{C} 44$ & $\mathrm{BD}^{*}(1) \mathrm{C} 37-\mathrm{C} 38$ & 6.39 \\
\hline \multicolumn{6}{|l|}{$\pi \rightarrow \pi^{*}$} \\
\hline $\mathrm{BD}(2) \mathrm{N} 3-\mathrm{C} 20$ & BD*(2)N4-C21 & 45.28 & $\mathrm{BD}(2) \mathrm{N} 3-\mathrm{C} 19$ & $\mathrm{BD}^{*}(2) \mathrm{N} 5-\mathrm{C} 20$ & 38.69 \\
\hline $\mathrm{BD}(2) \mathrm{N} 3-\mathrm{C} 20$ & BD*(2)N5-C22 & 4.65 & $\mathrm{BD}(2) \mathrm{N} 3-\mathrm{C} 19$ & $\mathrm{BD}^{*}(2) \mathrm{N} 6-\mathrm{C} 36$ & 4.66 \\
\hline $\mathrm{BD}(2) \mathrm{N} 4-\mathrm{C} 21$ & BD*(2)N3-C20 & 4.93 & $\mathrm{BD}(2) \mathrm{N} 5-\mathrm{C} 20$ & $\mathrm{BD}^{*}(2) \mathrm{N} 3-\mathrm{C} 19$ & 4.60 \\
\hline $\mathrm{BD}(2) \mathrm{N} 4-\mathrm{C} 21$ & BD*(2)N5-C22 & 38.58 & $\mathrm{BD}(2) \mathrm{N} 5-\mathrm{C} 20$ & $\mathrm{BD}^{*}(2) \mathrm{N} 6-\mathrm{C} 36$ & 44.78 \\
\hline $\mathrm{BD}(2) \mathrm{N} 4-\mathrm{C} 21$ & BD*(1)N6-C21 & 5.66 & $\mathrm{BD}(2) \mathrm{N} 6-\mathrm{C} 36$ & $\mathrm{BD}^{*}(2) \mathrm{N} 3-\mathrm{C} 19$ & 38.96 \\
\hline $\mathrm{BD}(2) \mathrm{N} 5-\mathrm{C} 22$ & BD*(2)N3-C20 & 47.40 & $\mathrm{BD}(2) \mathrm{N} 6-\mathrm{C} 36$ & $\mathrm{BD}^{*}(2) \mathrm{N} 5-\mathrm{C} 20$ & 5.07 \\
\hline $\mathrm{BD}(2) \mathrm{N} 5-\mathrm{C} 22$ & $\mathrm{BD}^{*}(2) \mathrm{N} 4-\mathrm{C} 21$ & 4.88 & $\mathrm{BD}(2) \mathrm{N} 8-\mathrm{C} 44$ & $\mathrm{BD}^{*}(2) \mathrm{C} 37-\mathrm{C} 42$ & 11.51 \\
\hline BD(2)N7-C30 & $\mathrm{BD}^{*}(2) \mathrm{C} 23-\mathrm{C} 28$ & 11.48 & $\mathrm{BD}(2) \mathrm{C} 9-\mathrm{C} 11$ & $\mathrm{BD}^{*}(2) \mathrm{C} 13-\mathrm{C} 14$ & 17.56 \\
\hline $\mathrm{BD}(2) \mathrm{C} 9-\mathrm{C} 11$ & $\mathrm{BD}^{*}(2) \mathrm{C} 13-\mathrm{C} 15$ & 17.18 & BD(2)C9-C11 & $\mathrm{BD}^{*}(2) \mathrm{C} 16-\mathrm{C} 18$ & 19.86 \\
\hline $\mathrm{BD}(2) \mathrm{C} 9-\mathrm{C} 11$ & $\mathrm{BD}^{*}(2) \mathrm{C} 17-\mathrm{C} 19$ & 20.4 & $\mathrm{BD}(2) \mathrm{C} 13-\mathrm{C} 14$ & $\mathrm{BD}^{*}(2) \mathrm{C} 9-\mathrm{C} 11$ & 21.19 \\
\hline $\mathrm{BD}(2) \mathrm{C} 13-\mathrm{C} 15$ & BD*(2)C9-C11 & 22.41 & $\mathrm{BD}(2) \mathrm{C} 13-\mathrm{C} 14$ & $\mathrm{BD}^{*}(2) \mathrm{C} 16-\mathrm{C} 18$ & 16.81 \\
\hline $\mathrm{BD}(2) \mathrm{C} 13-\mathrm{C} 15$ & $\mathrm{BD}^{*}(2) \mathrm{C} 17-\mathrm{C} 19$ & 18.66 & $\mathrm{BD}(2) \mathrm{C} 16-\mathrm{C} 18$ & BD*(2)C9-C11 & 18.55 \\
\hline $\mathrm{BD}(2) \mathrm{C} 17-\mathrm{C} 19$ & BD*(2)C9-C11 & 18.26 & $\mathrm{BD}(2) \mathrm{C} 16-\mathrm{C} 18$ & $\mathrm{BD}^{*}(2) \mathrm{C} 13-\mathrm{C} 14$ & 23.75 \\
\hline $\mathrm{BD}(2) \mathrm{C} 17-\mathrm{C} 19$ & $\mathrm{BD}^{*}(2) \mathrm{C} 13-\mathrm{C} 15$ & 21.9 & $\mathrm{BD}(2) \mathrm{C} 37-\mathrm{C} 42$ & BD*(2)N8-C44 & 27.09 \\
\hline $\mathrm{BD}(2) \mathrm{C} 23-\mathrm{C} 28$ & BD*(2)N7-C30 & 27.29 & & & \\
\hline \multicolumn{6}{|l|}{$\mathrm{n} \rightarrow \pi^{*}$} \\
\hline $\mathrm{LP}(1) \mathrm{N} 1$ & BD*(2)N3-C20 & 59.13 & $\mathrm{LP}(1) \mathrm{N} 4$ & $\mathrm{BD}^{*}(2) \mathrm{N} 5-\mathrm{C} 20$ & 70.72 \\
\hline $\mathrm{LP}(1) \mathrm{N} 1$ & $\mathrm{BD}^{*}(2) \mathrm{C} 17-\mathrm{C} 19$ & 36.38 & LP(1)N7 & $\mathrm{BD}^{*}(2) \mathrm{N} 6-\mathrm{C} 36$ & 51.52 \\
\hline LP(1)N6 & BD*(2)N4-C21 & 51.37 & LP(1)N7 & $\mathrm{BD}^{*}(2) \mathrm{N} 8-\mathrm{C} 44$ & 23.23 \\
\hline LP(1)N6 & BD*(2)N7-C30 & 23.44 & LP(1)N7 & $\mathrm{BD}^{*}(2) \mathrm{C} 37-\mathrm{C} 42$ & 34.67 \\
\hline LP(1)N6 & $\mathrm{BD}^{*}(2) \mathrm{C} 23-\mathrm{C} 28$ & 34.89 & & & \\
\hline $\begin{array}{c}\mathrm{LP}(1) \mathrm{N} 8 \\
\mathrm{n} \rightarrow \sigma^{*}\end{array}$ & BD*(2)N5-C22 & 72.58 & & & \\
\hline $\mathrm{LP}(1) \mathrm{N} 3$ & BD*(1)N4-C21 & 12.25 & $\mathrm{LP}(1) \mathrm{N} 3$ & $\mathrm{BD}^{*}(1) \mathrm{N} 5-\mathrm{C} 20$ & 12.07 \\
\hline $\mathrm{LP}(1) \mathrm{N} 3$ & $\mathrm{BD}^{*}(1) \mathrm{N} 5-\mathrm{C} 20$ & 12.16 & LP(1)N3 & $\mathrm{BD}^{*}(1) \mathrm{N} 6-\mathrm{C} 19$ & 12.90 \\
\hline $\mathrm{LP}(1) \mathrm{N} 4$ & $\mathrm{BD}^{*}(1) \mathrm{N} 3-\mathrm{C} 21$ & 12.99 & $\mathrm{LP}(1) \mathrm{N} 4$ & $\mathrm{BD}^{*}(1) \mathrm{C} 21-\mathrm{H} 23$ & 4.79 \\
\hline $\mathrm{LP}(1) \mathrm{N} 4$ & BD*(1)N5-C22 & 12.74 & LP(1)N5 & BD*(1)N3-C20 & 12.09 \\
\hline LP(1)N5 & BD*(1)N3-C20 & 13.20 & LP(1)N5 & $\mathrm{BD}^{*}(1) \mathrm{N} 6-\mathrm{C} 36$ & 12.63 \\
\hline $\mathrm{LP}(1) \mathrm{N} 5$ & BD*(1)N4-C22 & 11.88 & LP(1)N6 & $\mathrm{BD}^{*}(1) \mathrm{N} 3-\mathrm{C} 19$ & 12.99 \\
\hline LP(1)N7 & BD*(1)N6-C23 & 6.89 & LP(1)N6 & $\mathrm{BD}^{*}(1) \mathrm{N} 5-\mathrm{C} 36$ & 12.60 \\
\hline LP(1)N7 & $\mathrm{BD}^{*}(1) \mathrm{C} 28-\mathrm{C} 30$ & 6.08 & $\mathrm{LP}(1) \mathrm{N} 8$ & $\mathrm{BD}^{*}(1) \mathrm{N} 7-\mathrm{C} 37$ & 6.87 \\
\hline $\mathrm{LP}(1) \mathrm{N} 8$ & $\mathrm{BD}^{*}(1) \mathrm{C} 44-\mathrm{C} 47$ & 4.48 & & & \\
\hline
\end{tabular}

${ }^{\text {a }}$ Atom numbering refer to Figure 5 .

\section{Conclusions}

Two new hybrids tethered pyrazole/piperidine/aniline moieties-based s-triazine privileged structure were synthesized in a high chemical yield using a very simple and efficient method. The supramolecular structures of $\mathbf{5 a}$ and $\mathbf{5 b}$ were quantitatively determined using Hirshfeld analysis. The calculated structures using DFT B3LYP/6-31G $(d, p)$ agreed very well with the experimental X-ray geometries. Moreover, calculated NMR spectra are found in very good correlations with the experimental data. These compounds 
well be further explored by our groups with other derivatives in the near future for their biological applications.

Supplementary Materials: The following are available online at https://www.mdpi.com/article/ 10.3390 / cryst11121500/s1, Crystal structure determination; protocol and sofwares utilized in this study for computational investigation; Figures S1-S12: ${ }^{1} \mathrm{HNMR},{ }^{13} \mathrm{CNMR}$, and IR spectrum for the synthezied compounds; Table S1-S4: Computational study investigation.

Author Contributions: Conceptualization, A.E.-F. and A.B.; methodology, I.S.; software, S.M.S. and M.H.; formal analysis, I.S. and M.H.; investigation, I.S.; resources, A.E.-F. and A.B.; data curation, I.S., S.M.S., M.H. and A.A.; writing—original draft preparation, S.M.S., M.H. and A.B.; writing—review and editing, S.M.S., A.B. and A.E.-F.; visualization, A.B., and A.E.-F.; supervision, A.A., A.B. and A.E.-F.; project administration, A.E.-F. and A.B.; funding acquisition, A.B. All authors have read and agreed to the published version of the manuscript.

Funding: Researchers Supporting Project number (RSP-2021/64), King Saud University, Riyadh, Saudi Arabia.

Acknowledgments: The authors would like to extend their sincere appreciation to the Researchers Supporting Project (RSP-2021/64), King Saud University, Riyadh, Saudi Arabia.

Conflicts of Interest: The authors declare no conflict of interest.

\section{References}

1. Barakat, A.; El-Faham, A.; Haukka, M.; Al-Majid, A.M.; Soliman, S.M. s-Triazine pincer ligands: Synthesis of their metal complexes, coordination behavior, and applications. Appl. Organomet. Chem. 2021, 35, e6317. [CrossRef]

2. Dugan, J.; Pollyea, D. Enasidenib for the treatment of acute myeloid leukemia. Expert Rev. Clin. Pharmacol. 2018, 11, 755-760. [CrossRef]

3. Kim, E.S. Enasidenib: First global approval. Drugs 2017, 77, 1705-1711. [CrossRef] [PubMed]

4. Singh, U.; Bhat, H.; Gahtori, P. Antifungal activity, SAR and physicochemical correlation of some thiazole-1, 3, 5-triazine derivatives. J. Mycol. Med. 2012, 22, 134-141. [CrossRef]

5. Shanmugam, M.; Narayanan, K.; Chidambaranathan, V.; Kabilan, S. Synthesis, spectral characterization and antimicrobial studies of novel s-triazine derivatives. Spectrochim. Acta Mol. Biomol. Spectrosc. 2013, 105, 383-390. [CrossRef] [PubMed]

6. Shah, D.R.; Modh, R.P.; Chikhalia, K.H. Privileged s-triazines: Structure and pharmacological applications. Future Med. Chem. 2014, 6, 463-477.

7. Shanmugakala, R.; Tharmaraj, P.; Sheela, C.; Chidambaranathan, N. Transition metal complexes of s-triazine derivative: New class of anticonvulsant, antiinflammatory, and neuroprotective agents. Med. Chem. Res. 2014, 23, 329-342. [CrossRef]

8. Menicagli, R.; Samaritani, S.; Signore, G.; Vaglini, F.; Dalla Via, L. In vitro cytotoxic activities of 2-Alkyl-4,6-diheteroalkyl-1,3,5triazines: New molecules in anticancer research. J. Med. Chem. 2004, 47, 4649-4652. [CrossRef]

9. Viira, B.; Selyutina, A.; García-Sosa, A.T.; Karonen, M.; Sinkkonen, J.; Merits, A.; Maran, U. Design, discovery, modelling, synthesis, and biological evaluation of novel and small, low toxicity s-triazine derivatives as HIV-1 non-nucleoside reverse transcriptase inhibitors. Biorg. Med. Chem. 2016, 24, 2519-2529. [CrossRef] [PubMed]

10. El-Gazzar, A.-R.B.; Hafez, H.N. Synthesis of 4-substituted pyrido [2, 3-d] pyrimidin-4 (1H)-one as analgesic and anti-inflammatory agents. Bioorg. Med. Chem. Lett. 2009, 19, 3392-3397. [CrossRef]

11. Behki, R.; Topp, E.; Dick, W.; Germon, P. Metabolism of the herbicide atrazine by Rhodococcus strains. Appl. Environ. Microbiol. 1993, 59, 1955-1959. [CrossRef] [PubMed]

12. Sharma, A.; Ghabbour, H.; Khan, S.T.; Beatriz, G.; Albericio, F.; El-Faham, A. Novel pyrazolyl-s-triazine derivatives, molecular structure and antimicrobial activity. J. Mol. Struct. 2017, 1145, 244-253. [CrossRef]

13. Mikhaylichenko, S.N.; Patel, S.M.; Dalili, S.; Chesnyuk, A.A.; Zaplishny, V.N. Synthesis and structure of new 1, 3, 5-triazinepyrazole derivatives. Tetrahedron Lett. 2009, 50, 2505-2508. [CrossRef]

14. Lasri, J.; Haukka, M.; Al-Rasheed, H.H.; Abutaha, N.; El-Faham, A.; Soliman, S.M. Synthesis, Structure and In Vitro Anticancer Activity of Pd(II) Complex of Pyrazolyl-s-Triazine Ligand; A New Example of Metal-Mediated Hydrolysis of $s$-Triazine Pincer Ligand. Crystals 2021, 11, 119. [CrossRef]

15. Pathak, P.; Shukla, P.K.; Kumar, V.; Kumar, A.; Verma, A. Quinazoline clubbed 1,3,5-triazine derivatives as VEGFR2 kinase inhibitors: Design, synthesis, docking, in vitro cytotoxicity and in ovo antiangiogenic activity. Inflammopharmacology 2018, 26, 1441-1453. [CrossRef]

16. Pathak, P.; Rimac, H.; Grishina, M.; Verma, A.; Potemkin, V. Hybrid Quinazoline 1, 3, 5-Triazines as Epidermal Growth Factor Receptor (EGFR) Inhibitors with Anticancer Activity: Design, Synthesis, and Computational Study. ChemMedChem 2021, 16, 822-838. [CrossRef]

17. Osman, S.M.; Alasmary, F.A.; Kenawy, E.R.; Aly, E.S.A.; Khattab, S.N.; El-Faham, A. Synthesis, characterization and comparative thermal degradation kinetics of $s$-Triazine based polymers. J. Polym. Res. 2021, 28, 1-12. [CrossRef] 
18. Liao, J.H.; Lai, C.Y.; Yang, C.L. Synthesis, Characterization and Photoluminescence of Lanthanide Metal-organic Frameworks, Constructed from Triangular 4, 4', 4 "'-s-triazine-1, 3, 5-triyl-p-aminobenzoate Ligands. J. Chin. Chem. Soc. 2014, 61, 1115-1120. [CrossRef]

19. Gomes, R.; Bhaumik, A. A new triazine functionalized luminescent covalent organic framework for nitroaromatic sensing and $\mathrm{CO}_{2}$ storage. RSC Adv. 2016, 6, 28047-28054. [CrossRef]

20. Liu, A.; Zhang, J.; Lv, X. Novel hydrazine-bridged covalent triazine polymer for CO2 capture and catalytic conversion. Chinese J. Catal. 2018, 39, 1320-1328. [CrossRef]

21. Wu, M.-X.; Yang, Y.-W. Applications of covalent organic frameworks (COFs): From gas storage and separation to drug delivery. Chin Chem Lett. 2017, 28, 1135-1143. [CrossRef]

22. Barakat, A.; El-Senduny, F.F.; Almarhoon, Z.; Al-Rasheed, H.H.; Badria, F.A.; Al-Majid, A.M.; Ghabbour, H.A.; El-Faham, A. Synthesis, X-ray crystal structures, and preliminary antiproliferative activities of new s-triazine-hydroxybenzylidene hydrazone derivatives. J. Chem. 2019, 2019. [CrossRef]

23. Barakat, A.; Soliman, S.M.; El-Faham, A.; Ali, M.; Al-Majid, A.M.; Yousuf, S.; Choudhary, M.I. Three multi-components reaction: Synthesis and X-ray single-crystal of hydroacridinone-based hydrazino-s-triazine derivative as a new class of urease inhibitor. Crystals. 2020, 10, 14. [CrossRef]

24. Soliman, S.M.; Lasri, J.; Haukka, M.; Elmarghany, A.; Al-Majid, A.M.; El-Faham, A.; Barakat, A. Synthesis, X-ray structure, Hirshfeld analysis, and DFT studies of a new Pd (II) complex with an anionic s-triazine NNO donor ligand. J. Mol. Struct. 2020, 1217, 128463. [CrossRef]

25. Farooq, M.; Sharma, A.; Almarhoon, Z.; Al-Dhfyan, A.; El-Faham, A.; Abu Taha, N.; Wadaan, M.A.M.; de la Torre, B.G.; Albericio, F. Design and synthesis of mono-and di-pyrazolyl-s-triazine derivatives, their anticancer profile in human cancer cell lines, and in vivo toxicity in zebrafish embryos. Bioorg. Chem. 2019, 87, 457-464. [CrossRef]

26. Sanders, M.A.; Brahemi, G.; Nangia-Makker, P.; Balan, V.; Morelli, M.; Kothayer, H.; Westwell, A.D.; Shekhar, M.P. Novel inhibitors of Rad6 ubiquitin conjugating enzyme: Design, synthesis, identification, and functional characterization. Mol. Cancer Ther. 2013, 12, 373-383. [CrossRef] [PubMed]

27. Balaha, M.F.; El-Hamamsy, M.H.; El-Din, N.A.; El-Mahdy, N.A. Synthesis, evaluation and docking study of 1, 3, 5-triazine derivatives as cytotoxic agents against lung cancer. J. Appl. Pharm. Sci. 2016, 6, 28-45. [CrossRef]

28. Raghu, M.S.; Kumar, C.P.; Prashanth, M.K.; Kumar, K.Y.; Prathibha, B.S.; Kanthimathi, G.; Alissa, S.A.; Alghulikah, H.A.; Osman, S.M. Novel 1, 3, 5-triazine-based pyrazole derivatives as potential antitumor agents and EFGR kinase inhibitors: Synthesis, cytotoxicity, DNA binding, molecular docking and DFT studies. New. J. Chem. 2021, 45, 13909-13924. [CrossRef]

29. Srivastava, J.K.; Pillai, G.G.; Bhat, H.R.; Verma, A.; Singh, U.P. Design and discovery of novel monastrol-1, 3, 5-triazines as potent anti-breast cancer agent via attenuating epidermal growth factor receptor tyrosine kinase. Sci. Rep. 2017, 7, 1-18. [CrossRef]

30. Rikagu Oxford Diffraction. CrysAlisPro; Agilent Technologies Inc.: Yarnton, UK, 2020.

31. Sheldrick, G.M. SHELXT-Integrated space-group and crystal-structure determination. Acta Cryst. 2015, A71, 3-8. [CrossRef]

32. Sheldrick, G.M. Crystal structure refinement with SHELXL. Acta Cryst. 2015, C71, 3-8.

33. Hübschle, C.B.; Sheldrick, G.M.; Dittrich, B. ShelXle: A Qt graphical user interface for SHELXL. B. J. Appl. Cryst. 2011, 44, 1281-1284. [CrossRef] [PubMed]

34. Turner, M.J.; McKinnon, J.J.; Wolff, S.K.; Grimwood, D.J.; Spackman, P.R.; Jayatilaka, D.; Spackman, M.A. Crystal Explorer17; University of Western Australia: 2017. Available online: http:/ / hirshfeldsurface.net (accessed on 17 July 2019).

35. Frisch, M.J.; Trucks, G.W.; Schlegel, H.B.; Scuseria, G.E.; Robb, M.A.; Cheeseman, J.R.; Scalmani, G.; Barone, V.; Mennucci, B.; Petersson, G.A.; et al. GAUSSIAN 09; Revision A02; Gaussian Inc.: Wallingford, CT, USA, 2009.

36. GaussView; Version 4.1; Denningto, R., II; Keith, T.; Millam, J. (Eds.) Semichem Inc.: Shawnee Mission, KS, USA, 2007.

37. Reed, A.E.; Curtiss, L.A.; Weinhold, F. Intermolecular interactions from a natural bond orbital, donor-acceptor viewpoint. Chem. Rev. 1988, 88, 899-926. [CrossRef]

38. Cheeseman, J.R.; Trucks, G.W.; Keith, T.A.; Frisch, M.J. A Comparison of Models for Calculating Nuclear Magnetic Resonance Shielding Tensors. J. Chem. Phys. 1996, 104, 5497-5509. [CrossRef]

39. Marten, B.; Kim, K.; Cortis, C.; Friesner, R.A.; Murphy, R.B.; Ringnalda, M.N.; Sitkoff, D.; Honig, B. New Model for Calculation of Solvation Free Energies: Correction of Self-Consistent Reaction Field Continuum Dielectric Theory for Short-Range HydrogenBonding Effects. J. Phys. Chem. 1996, 100, 11775-11788. [CrossRef]

40. Tannor, D.J.; Marten, B.; Murphy, R.; Friesner, R.A.; Sitkoff, D.; Nicholls, A.; Ringnalda, M.; Goddard, W.A.; Honig, B. Accurate first principles calculation of molecular charge distributions and solvation energies from ab initio quantum mechanics and continuum dielectric theory. J. Am. Chem. Soc. 1994, 116, 11875-11882. [CrossRef]

41. Foresman, J.B.; Frisch, Æ. Exploring Chemistry with Electronic Structure Methods, 2nd ed.; Gaussian: Pittsburgh, PA, USA, 1996.

42. Chang, R. Chemistry, 7th ed.; McGraw-Hill: New York, NY, USA, 2001.

43. Parr, R.G.; Yang, W. Density-Functional Theory of Atoms and Molecules; Oxford University Press: New York, NY, USA, 1989.

44. Parr, R.G.; Szentpaly, L.V.; Liu, S. Electrophilicity index. J. Am. Chem. Soc. 1999, 121, 1922-1924. [CrossRef]

45. Hubert Joe, I.; Kostova, I.; Ravikumar, C.; Amalanathan, M.; Pinzaru, S.C. Theoretical and vibrational spectral investigation of sodium salt of acenocoumarol. J. Raman Spectrosc. 2009, 40, 1033-1038.

46. Sebastian, S.; Sundaraganesan, N.; Spectrochim. The spectroscopic (FT-IR, FT-IR gas phase, FT-Raman and UV) and NBO analysis of 4-Hydroxypiperidine by density functional method. Acta Part A Mol. Biomol. Spectrosc. 2010, 75, 941-952. [CrossRef] 